\title{
How do social status and tree architecture influence radial growth, wood density and drought response in spontaneously established oak forests?
}

\author{
Raquel Alfaro-Sánchez ${ }^{1,2} \cdot$ Elena Valdés-Correcher ${ }^{3} \cdot$ Josep Maria Espelta $^{1} \cdot$ Arndt Hampe $^{3} \cdot$ Didier Bert $^{3}$
}

Received: 11 October 2019 / Accepted: 26 March 2020 / Published online: 25 May 2020

(C) INRAE and Springer-Verlag France SAS, part of Springer Nature 2020

\begin{abstract}
- Key message During the past decades, a multitude of oak stands have spontaneously established across the pinedominated landscapes of the French Landes de Gascogne. Yet their future performance under modern climate change is unknown. We show that coppiced, dominant trees are most prepared to cope with drought episodes, displaying higher basal area increment and lower sensitivity to extreme events.

- Context Forest stands dominated by pedunculate oak (Quercus robur L.) have spontaneously established across the pinedominated landscapes of the French Landes de Gascogne. These oak stands are typically unmanaged and unsystematically coppiced, resulting in mixtures of single- and multi-stemmed (coppiced) trees.

- Aims To determine the ability of spontaneous oak forest stands to face climate change-related hazards, by analysing differences in growth (tree-ring width and basal area increment-BAI), wood density and climate sensitivity depending on their tree architecture (single- vs multi-stemmed trees) and their social status in the forest.

- Methods We exhaustively cored 15 oak stands $(n=657$ trees). We compared stand characteristics and climate sensitivity between tree architectures considering two sampling designs, either all sampled trees (the exhaustive sampling) or those with a dominant status (dominant sampling). At the tree level, we used linear mixed effects models to compare wood density and growth between tree architectures and the trees' social status within the canopy layer (dominant- vs non-dominant trees).

- Results Multi-stemmed trees exhibited higher wood density than single-stemmed trees for diameters $>30 \mathrm{~cm}$. Dominant multistemmed trees showed lower sensitivity to extreme events (pointer years), higher BAI but lower annual growth rates than dominant single-stemmed trees.

- Conclusion Dominant multi-stemmed trees are potentially the most prepared ones to cope with increasing soil water deficit following drought episodes, at least during the first 60 years of the life of the tree. The vulnerability to face harsher climate conditions for $Q$. robur stands can be misled when using a dominant sampling design.
\end{abstract}

Keywords Dominant trees · Forest expansion · Pointer years $\cdot$ Quercus robur L. · Single- and multi-stemmed trees · Wood density

Handling editor: Irene Martin-Fores

This article is part of the topical collection on Establishment of secondgrowth forests in human landscapes: ecological mechanisms and genetic consequences

Raquel Alfaro-Sánchez

r.alfarosanchez@gmail.com

Elena Valdés-Correcher

elena.valdes-correcher@inra.fr

Josep Maria Espelta

josep.espelta@uab.cat

Arndt Hampe

arndt.hampe@inrae.fr
Didier Bert

didier.bert@inra.fr

1 CREAF, Centre de Recerca Ecològica i Aplicacions Forestals, E08193 Bellaterra (Cerdanyola de Vallès), Catalonia, Spain

2 Wilfrid Laurier University, Waterloo, Ontario, Canada

3 BIOGECO, INRAE, Univ. Bordeaux, 33610 Cestas, France 


\section{Introduction}

Extensive forest expansion has occurred in many parts of Southern Europe during the last decades as a consequence of changing land use and rural abandonment, and the process is expected to continue in the near future (Schröter et al. 2005; Palmero-Iniesta et al. 2020). Novel forest stands have the capacity to rapidly attain a high level of multifunctionality and deliver diverse ecosystem services (Cruz-Alonso et al. 2019; Pugh et al. 2019). Oaks were once prominent tree species in the Landes de Gascogne, Southwest France, and are currently increasing again in abundance and spatial extent by means of spontaneous reforestation. Broadleaf forest stands dominated by pedunculate oak (Quercus robur L.) represent important foci of biodiversity within the pine-dominated landscape of the region (Barbaro et al. 2007; Valdés-Correcher et al. 2019) that have significant beneficial effects on the health of surrounding pine plantations (Samalens and Rossi 2011; Dulaurent et al. 2012). Such stands are typically small and not systematically managed by landowners or administrations, yet they are used by local people for gathering firewood and non-timber products (e.g. mushroom, fruits), hunting and other recreational activities. Promoting the natural regeneration of spontaneous oak forest stands across the Landes de Gascogne forest landscape can thus help sustain biodiversity, improve forest resistance to natural and anthropogenic disturbances and facilitate management and silviculture.

Many temperate and boreal forests worldwide have experienced recent increases in annual growth rates and declines in wood density in response to warmer temperatures, extended growing seasons and higher air $\mathrm{CO}_{2}$ concentrations (Bontemps et al. 2013; Pretzsch et al. 2018). This trend in fast tree growth and concomitant high carbon storage is even stronger in second-growth forests established (either actively or passively) on former agricultural or pastoral grounds, as a consequence of land-use legacies (Mausolf et al. 2018; Alfaro-Sánchez et al. 2019). However, such forests have also been reported to be subject to increased tree sensitivity to soil water deficit following drought episodes (Vilà-Cabrera et al. 2017; Alfaro-Sánchez et al. 2019).

Modern climate change represents a threat for forests as it leads to an increasing frequency of abiotic (e.g. storms or droughts) and biotic (e.g. pest outbreaks) hazards, but we ignore how imminent and rapid such a deterioration may be (Lloret et al. 2012), especially for those forests that are located near the southern range limits of dominant tree species (Allen et al. 2010; Greenwood et al. 2017). In the sandy plains of the Landes de Gascogne, many spontaneous forest stands of pedunculate oak could be highly susceptible to projected climate change considering that this species is currently approaching the limits of its ecophysiological tolerance. The extensive monospecific plantations of maritime pine that dominate the landscape are also under particular risk. For instance, the storm Klaus in January 2009 destroyed an estimated 43 million $\mathrm{m}^{3}$ of pine trees (Colin et al. 2010), and the resulting woody debris promoted important outbreaks of bark beetles in following years. While such damages strongly exacerbate the costs of forest management (Hautdidier et al. 2018), recent research indicates that these might be efficiently reduced by drawing on natural processes.

Diverse intrinsic and extrinsic drivers can trigger the resistance of individual trees to soil water deficit. One such trigger is their architecture and associated root-to-shoot ratio. Tree growth in coppiced oaks (with several stems that resprouted from the stump) has been shown to be less influenced by soil water deficit than non-coppiced oaks (with a single stem; Stojanović et al. 2016, 2017; but see Fedorová et al. 2018), although these positive effects may be transient in time (Cotillas et al. 2009; Sanchez-Humanes and Espelta 2011). On the other hand, the social status of a tree within the canopy layer can also influence its growth and resistance to soil water deficit. Dominant trees can show four times higher growth rates than the rest of the population (Nehrbass-Ahles et al. 2014). Studying dominant trees can lead to biased results and conclusions about the sensitivity to climate extremes of the entire population when they are the only ones sampled (Cherubini et al. 1998). Previous studies on how the size or social status affect the response of growth to climate are inconclusive for either coniferous or deciduous species (Lebourgeois et al. 2014 and references therein). For instance, dominant trees are either more sensitive to climate or less sensitive depending on the species and local environmental conditions (e.g. Zang et al. 2012).

Both architecture and social status of trees are of particular relevance in spontaneous oak forests. They contain a high proportion of multi-stemmed trees as a result of historical silvicultural treatments and unsystematic coppicing for firewood by local populations. In addition, their establishment through natural secondary succession typically generates a heterogeneous distribution of tree sizes with a mixture of some dominant individuals (often the founders of the stand) and many smaller individuals resulting from subsequent recruitment. Both triggers should be taken into account when assessing individual climate-growth relationships.

Here, we assessed patterns of radial tree growth in spontaneous pedunculate oak stands established during the twentieth century in the Landes de Gascogne. The aim was to determine whether trees present differences in growth rates, wood density and sensitivity to climate depending on their tree architecture (single- vs multi-stemmed trees) and their social status in the forest (dominant vs non-dominant trees). We hypothesised the following: (1) Multi-stemmed (coppiced) trees should display higher growth during the first decades of their life and consequently lower wood density; this effect would be expected as a consequence of their pre-established root system (Zhu et al. 2012; Pemán et al. 2017). (2) Multi-stemmed trees 
should display lower sensitivity to extreme climatic events, such as severe droughts, than single-stemmed trees; sensitivity is tested by analysing associations between temperature, precipitation and soil water deficit with growth and by identifying event and pointer years. (3) Dominant individuals, regardless their growth form, should exhibit higher growth and lower climate sensitivity compared with non-dominant trees. Ultimately, our results should help better understand what type of forest management can support spontaneous oak forests to cope with soil water deficit following drought episodes, and thus to preserve these forests and the ecological services they provide in the long term.

\section{Methods}

\subsection{Study area and sites}

The study area was located in the Landes de Gascogne $\left(44^{\circ}\right.$ $41^{\prime} \mathrm{N}, 00^{\circ} 51^{\prime} \mathrm{W}$ ) southwest of Bordeaux, France (Fig. 1). The region is characterised by an oceanic climate with mean annual temperature of $13.3{ }^{\circ} \mathrm{C}$ and annual precipitation of $923 \mathrm{~mm}$ for the period 1949-2017 (Météo-France data retrieved from the INRA CLIMATIK database). The area is covered by extensive plantations of maritime pine (Pinus pinaster Ait.) with scattered broadleaved forest stands that are dominated by pedunculate oak with other species such as holm oak (Q. ilex L.), Pyrenean oak (Q. pyrenaica Willd.), birch (Betula pendula L.) or willows (Salix spp.) being present in lower abundance. Soils are almost completely composed of coarse sand, poor, acidic and quite organic. They vary from typic haplorthod spodosols to haplohumod spodosols (or umbric endoaquod spodosols; USDA classification), depending of the depth of the water table (Augusto et al. 2008). As a consequence, trees often suffer from soil water excess in winter and soil water deficit in summer.

We selected 15 spontaneously established pedunculate oak stands from the original set of 18 stands used by ValdésCorrecher et al. (2019; see Table 4 and the cited paper for details on stand characteristics). Their location is shown in Fig. 1. We confirmed on aerial photographs from the 1950s (https://remonterletemps.ign.fr) that no or only a few trees were present on each spot at that time. We measured the stand area as the minimum polygon including all trees and calculated the tree density (trees $\mathrm{ha}^{-1}$ ) of each stand using the R package spatstat (Baddeley et al. 2015, Table 4). As corresponds to oak forests not systematically managed, the selected stands were characterised by a heterogeneous distribution of tree sizes with some large, dominant individuals - often the original founder trees of the stand - and many smaller individuals resulting from subsequent, successive recruitment.

\subsection{Characterisation and classification of trees}

We carried out an exhaustive sampling of the 15 forest stands including all individuals with a stem diameter at breast height (DBH) $\geq 3 \mathrm{~cm}$ (657 trees in total). We mapped each tree; counted the number of stems and measured the canopy projection, total height, and the DBH of all stems (AlfaroSánchez et al. 2020). Each tree was then classified as either multi-stemmed (= putatively coppiced) or single-stemmed (= non-coppiced) for subsequent analyses (Table 4).

To determine the role of trees' social status, we classified individuals either as dominant or as non-dominant based on their aboveground biomass. We used biomass and not height to assess the dominance of the trees, because for the target mixed oak stands, composed by single- and multi-stemmed trees, height alone does not properly capture dominance (Cotillas et al. 2016). The aboveground biomass was calculated following the stem biomass equation of Balboa-Murias et al. (2006) for pedunculate oak stands in NW Spain:

$$
\begin{aligned}
W_{\text {stem }}= & -5.714+0.018 \times \mathrm{DBH}^{2} \\
& \times \text { Height }\left(R^{2}=0.94\right)
\end{aligned}
$$

where $W$ represents the dry weight of the stem $(\mathrm{kg})$. Trees above the 75th percentile per stand were considered dominant. We followed this approach to ensure a minimum number of dominant trees even for the smallest stands. By selecting the dominant trees per patch, we aimed to adopt a dominant sampling design. This design is commonly used for dendrochronological studies. Most such studies tend to select only wellestablished, healthy trees that are not affected by competition, based on the assumption that the largest trees are also the oldest ones and consequently the ones that can provide the longest dendrochronological time series (revised in Nehrbass-Ahles et al. 2014).

\subsection{Dendrochronological sampling and growth measurements}

One increment core was extracted per tree at $30-40 \mathrm{~cm}$ above ground level using a Pressler increment borer $(5 \mathrm{~mm})$. Cores were air dried, planed with a cutter until rings were clearly visible with a stereomicroscope and scanned at 1200 d.p.i. Tree-ring widths were measured to an accuracy of $0.01 \mathrm{~mm}$ using the software WinDENDRO. Cross-dating of individual series was checked also using WinDENDRO. Previous studies have shown that young oak recruits in the area grow on average $10 \mathrm{~cm}$ in height per year (Gerzabek et al. 2017), so we adjusted tree age by adding 3 years to the number of tree rings counted at the height of coring. In addition, tree-ring width series were converted to basal area increment (BAI) 

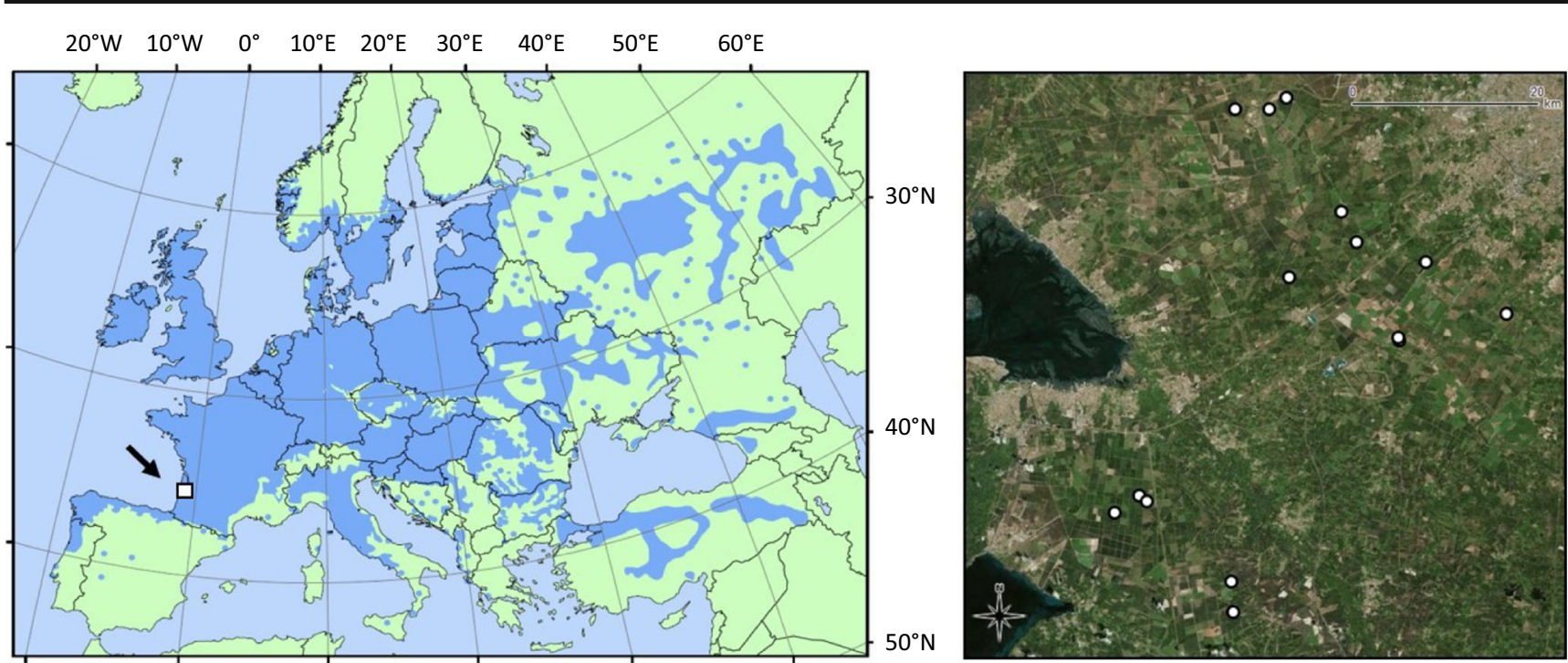

Fig. 1 Distribution range of $Q$. robur for Europe (map provided by EUFORGEN 2009; www.euforgen.org) and the general area (white square) where the study was conducted in the French Landes (left

measurements $\left(\mathrm{cm}^{2}\right)$. For multi-stemmed trees, we calculated the BAI using a correction factor:

Correction factor $=\frac{B A_{\text {tree }}}{B A_{\text {stem }}}$

where the $B A_{\text {tree }}$ corresponded to the basal area calculated of all stems of the tree, assuming symmetrical growth, and $B A_{\text {stem }}$ corresponded to the basal area of the cored stem.

All trees were also individually detrended with cubic smoothing splines of 30 years to remove non-climatic growth trends related to the increase in tree age and size (Cook and Kairiukstis 1990). Autocorrelation was removed from the tree-ring series (prewhitening) by utilising the detrend function with the Ar method within the R package dplR (Bunn 2008). Following this approach, we aimed to preserve the high-frequency signal (year-to-year variability) in order to reduce spurious correlations between long-term trends in radial growth and climate. Four tree-ring chronologies were built based on single- and multi-stemmed trees using tree-ring width series from either all sampled trees (hereafter termed 'exhaustive sampling') or only the dominant trees (hereafter 'dominant sampling'). Tree-level indexed ring width series for each group were averaged to build the four mean tree-ring chronologies by using a bi-weight robust mean. The four chronologies were then used in the climate-growth analyses (see next section). Mean interseries correlation, mean sensitivity and first-order autocorrelation (before prewhitening) were determined for each chronology with $d p l R$.

\subsection{Climate-growth analyses}

Monthly mean temperature and summed precipitation for the period 1949-2017 were obtained from the nearby climate panel). Location of the 15 recently established Q. robur stands (white dots on the right panel)

station of Mérignac (Météo France; 44 49' 53" N, $0^{\circ} 41^{\prime}$ $31 " \mathrm{~W})$. Soil water deficit was assessed through the Standardised Precipitation-Evapotranspiration Index (SPEI; Vicente-Serrano et al. 2010), a broadly used drought index based on precipitation and temperature data. SPEI was calculated for a time scale of 1, 3, 6 and 12 months using the $\mathrm{R}$ package SPEI (Vicente-Serrano et al. 2010). It uses the monthly difference between precipitation and potential evapotranspiration (PET). PET was calculated using the simplest empirical approach of climatic water balance that only requires monthly temperature.

We used the $\mathrm{R}$ package treeclim (Zang and Biondi 2015) to run Pearson correlation analyses between monthly and seasonal SPEI, precipitation and temperature data, and the four mean tree-ring chronologies, from April of the previous growing season to September of the year in which the ring was formed, considering the maximum overlapping period (Table 1). A bootstrapping procedure was used to test for significant correlations $(P<0.05)$. The variables SPEI and precipitation were highly correlated. We found higher correlations using the variable SPEI3 than using precipitation for the four mean tree-ring chronologies. Thus, we only report the results found for the variable SPEI-3.

The climate-growth analyses showed a high response in growth during high SPEI-3 values from June to July of the current year of tree-ring formation and during previous year's September to October. A significant negative response in growth to high temperatures during previous year's August to September was also identified. Therefore, we employed a 31-year running variation for June-July SPEI-3 (June-July and September-October SPEI-3 were highly correlated) and August-September temperatures for the period 1949-2017 in 
order to determine if climate variability has been increasing over time in the study area.

\subsection{Event and pointer years}

Negative or positive event years can be identified as abrupt decreases or increases in growth for individual tree-ring samples (Schweingruber et al. 1990). We adopted the normalisation in a moving window method and transformed annual treering width values for each sample to Cropper values by using a 5-year window (Cropper 1979), as described by AlfaroSánchez et al. (2019). A 13-year weighted low-pass filter was previously applied to tree-ring series (Fritts 1976). The low-pass filter improves the detection of event and pointer years in complacent series and is known to have little effect even in sensitive series (Cropper 1979).

A pointer year occurs when a high proportion of tree-ring series from a group of trees shows the same trend in a specific year (i.e. negative or positive event years; Schweingruber et al. 1990). Here, we set a minimum threshold of $50 \%$ of trees that should display either a negative or a positive event year for a particular year to be considered as pointer year. The period from 1975 to 2009 was used for the identification of pointer years. This period covered a representative number of trees in each of our four groups after applying the 13-year lowpass filter that truncates the tree-ring time series by 6 years at both ends. Then, we linked pointer years to extreme climatic events, including extremely dry, wet, warm and cold years defined as the 90th or 10th percentile values of the JuneJuly SPEI-3 time series (see next sections). Years were classified as negative or positive climate-linked pointer years when the year fell below the 10th or above the 90th percentiles of the June-July SPEI-3 time series during that year, respectively.

\subsection{Wood density measurements}

Wood density $\left(\mathrm{g} \mathrm{cm}^{-3}\right)$ was calculated from the same cores used for the tree-ring measurements following Williamson and Wiemann (2010). Cores were oven dried for at least $2 \mathrm{~h}$ at a temperature of $105{ }^{\circ} \mathrm{C}$ and weighted to obtain their dry weight. Then, their volume was obtained by submerging the core into water (the Archimedes principle), which is a reliable measurement for irregularly shaped samples. Finally, mean wood density was calculated as the dry weight of the core divided by its volume.

\subsection{Statistical analyses}

ANOVAs were applied to test for differences in DBH, height, canopy projection, biomass and tree age between single- and multi-stemmed trees, both for the exhaustive and the dominant sampling (significance level was set at $P<0.05$ ).

We performed linear mixed effects models (LMEMs; Zuur 2009) with the function 'Imer' from the lme4 package (Bates et al. 2015). Tree-level LMEMs were built for wood density and year-level LMEMs for tree-ring width and BAI across the first 60 years of the life of the trees. In the LMEM for wood density, the initial set of variables tested were architecture (single- or multi-stemmed), social status (dominant or nondominant), tree age, DBH and height as well as the secondorder interactions of the variables architecture and social status with the remaining variables. Height and canopy projection were highly correlated $r=0.62(P<0.001)$, so we only included the variable height in the models to avoid collinearity problems. The forest stand was included as a random effect. In the LMEMs for tree-ring width and BAI, the initial set of variables were architecture (single- or multi-stemmed trees), social status (dominant or non-dominant), cumulative ring width (only for tree-ring width), ring age, June-July SPEI-3, previous year's August-September temperature, and the second-order interactions of the variables architecture and social status with the remaining variables. Current June-July SPEI-3 and previous year's September-October SPEI-3 were highly correlated $r=0.65(P<0.001)$, so we only included the variable that displayed the highest climate-growth correlations for the four chronologies (i.e. June-July SPEI-3) in the models to avoid collinearity problems. We included as random effects the stand and the tree identity to account for the repeated measures across an individual. The influence of age during the first 60 years of life of the tree on ring width and BAI was modelled with a natural cubic spline with a B-spline basis with two knots.

The best model for each response variable was obtained using a backward elimination method on the full (saturated) models. We calculated marginal (i.e. the proportion of variance explained by fixed effects) and conditional (i.e. the proportion

multi-stemmed trees using the exhaustive and the dominant tree sampling (in parentheses). $\mathrm{AC} 1$ refers to the first-order autocorrelation
Table 1 Tree-ring width chronology statistics for pedunculate oak trees for expressed population signal (EPS) values above 0.85 and over a minimum of five trees. Four chronologies were built for single- and

\begin{tabular}{|c|c|c|c|c|c|}
\hline Architecture & Period & $n$ trees & Mean interseries correlation & Mean sensitivity & $\mathrm{AC} 1$ \\
\hline Single & 1951-2017 (1959-2017) & $446(64)$ & $0.37(0.40)$ & $0.34(0.29)$ & $0.123(0.149)$ \\
\hline Multi & $1954-2017(1955-2017)$ & $211(96)$ & $0.41(0.45)$ & $0.34(0.31)$ & $0.301(0.459)$ \\
\hline
\end{tabular}


of variance explained by fixed and random effects) $R^{2}$ for the best models with the MuMIn package (Barton 2018). All predictor variables were standardised to eliminate differences arising from the scale of measurements. All statistical analyses were performed using R version 3.5.1 (R Core Team 2018).

\section{Results}

\subsection{Composition of the stands}

We recorded a total of 446 (67.9\%) single-stemmed and 211 (32.1\%) multi-stemmed trees. The latter had on average $2.8 \pm$ 1.3 stems (mean $\pm \mathrm{SD}$ ). The multi-stemmed tree-ring width chronology displayed higher values than the single-stemmed one until the 1990s for the overall sample, corresponding with most of the extremely wet years recorded during the time series. After the 1990s, both chronologies overlapped (Fig. 2a). Mean interseries correlation and first-order autocorrelation were higher in multi-stemmed trees compared with single-stemmed ones in the overall sample, whereas mean sensitivity was similar between the two architectures (Table 1). DBH, aboveground biomass and canopy projection were significantly higher in multi-stemmed trees (mean \pm SE $30.5 \pm 0.9 \mathrm{~cm}$, $281 \pm 19 \mathrm{~kg}$ and $7.1 \pm 0.3 \mathrm{~m}^{2}$, respectively) compared with single-stemmed ones $(21.8 \pm 0.6 \mathrm{~cm}, 148 \pm 15 \mathrm{~kg}$ and $5.83 \pm$ $0.22 \mathrm{~m}^{2}$, respectively; Fig. 3a). In contrast, tree height and age did not differ between architectures (Fig. 3a).

Dominant trees (either single or multi-stemmed) exhibited a $30 \%$ larger canopy projection, accounted for $67 \%$ of the total biomass per stand and were $14 \%$ older (Fig. 3b). The proportion of multi-stemmed trees in this subgroup was markedly higher than in the overall sample $(60 \%$, Fig. 2). Dominant trees displayed higher mean interseries correlation, higher first-order autocorrelation and lower mean sensitivity compared with the overall sample and regardless the architecture (Table 1).

Tree-ring width chronologies for dominant trees displayed similar growth between architectures at the beginning of the time series, but since the 1970 s, the single-stemmed

\section{a. BAI-Exhaustive sampling}

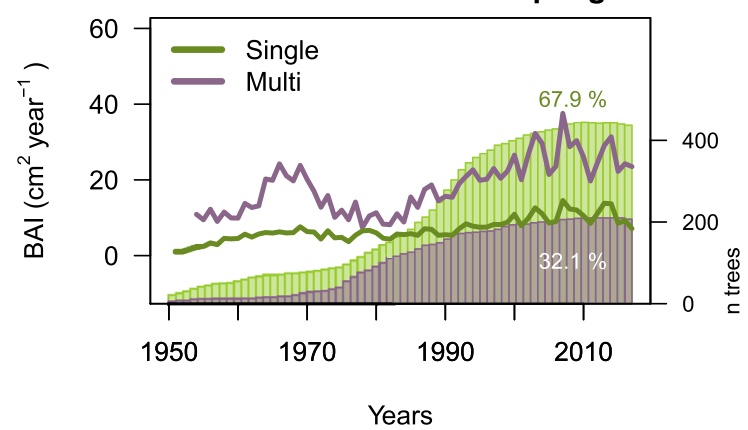

Fig. 2 Basal area increment (BAI) chronologies using the exhaustive (left panel) and the dominant tree sampling (right panel). The sample depth chronology displayed higher tree-ring width values (Fig. 2b). First-order autocorrelation and mean sensitivity were higher for dominant multi-stemmed trees compared with dominant single-stemmed trees (Table 1). No difference was found for $\mathrm{DBH}$, height, canopy projection, aboveground biomass and tree age between architectures for dominant trees (Fig. $3 b)$.

\subsection{Climate-growth associations}

Soil water deficit calculated for a timescale of 3 months (SPEI-3) displayed higher correlations with the four mean tree-ring chronologies than SPEI calculated for timescales of 1, 6 or 12 months. Higher SPEI values indicate wet conditions, i.e. low soil water deficit, and lower SPEI values indicate dry conditions, i.e. high soil water deficit. We found significant positive correlations between growth and SPEI-3 values during late spring and summer of the current year (June-July) and previous year's fall (September-October), regardless of the architecture or social status (Figs. 8 and 9). Significant negative correlations were also found in the two dominant chronologies and in the singlestemmed chronology from the exhaustive sampling between growth and temperatures for the previous year's summer (August-September; Figs. 8 and 9). Thus, for the exhaustive sampling, the multi-stemmed chronology displayed lower limitation by soil water deficit and summer temperature than the single-stemmed chronology whereas, for the dominant sampling, we found similar climate-growth associations between architectures (Figs. 8 and 9).

\subsection{Events and pointer years}

Successive extreme dry and warm years have been recorded in the study area since the early 2000s (Fig. 10), together with an increase in June-July SPEI-3 and previous year's AugustSeptember temperature variability. Accordingly, negative pointer years (PYs) for the four mean tree-ring chronologies were most common since the 2000s. The negative PYs 1976, 2005 and 2006 were linked to lower June-July SPEI-3 values.

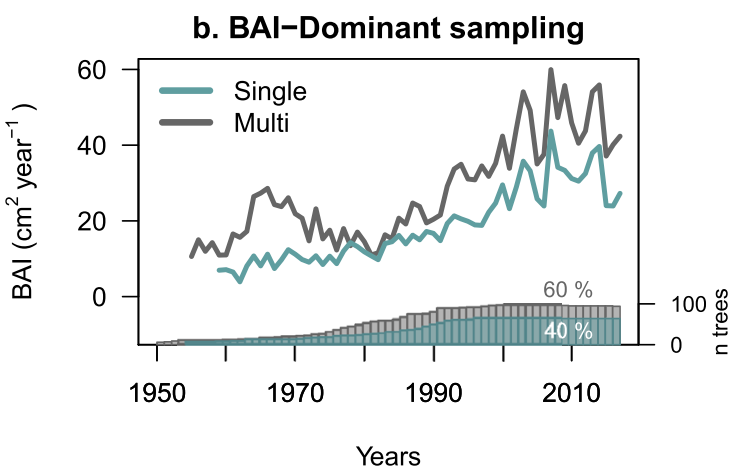

and the percentage of trees for single- and multi-stemmed trees are also shown for the exhaustive and dominant tree sampling 


\section{a. Exhaustive sampling}
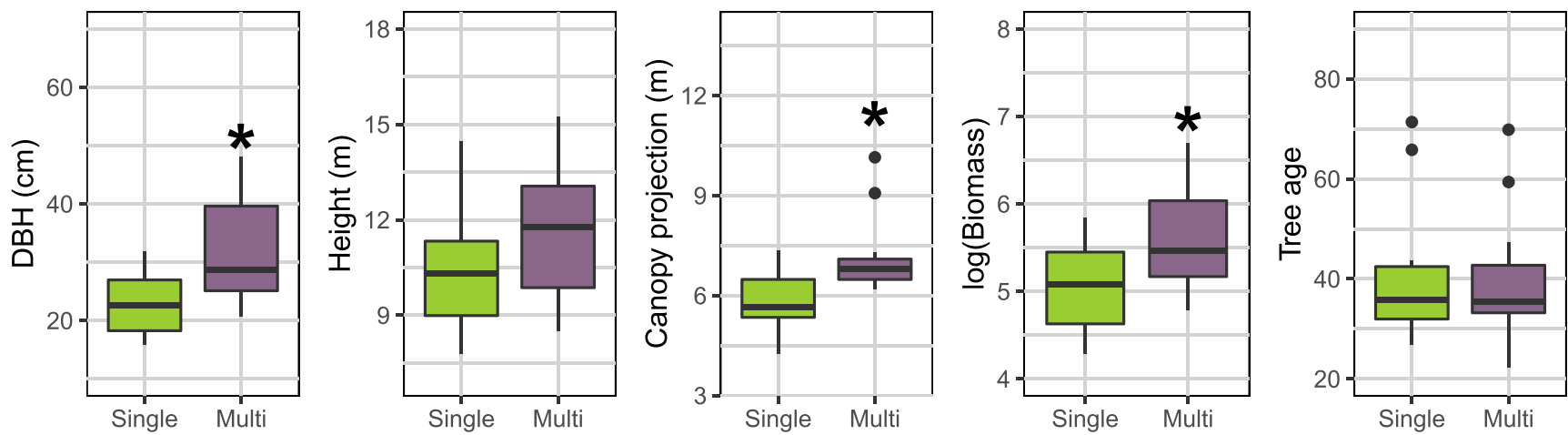

b. Dominant sampling
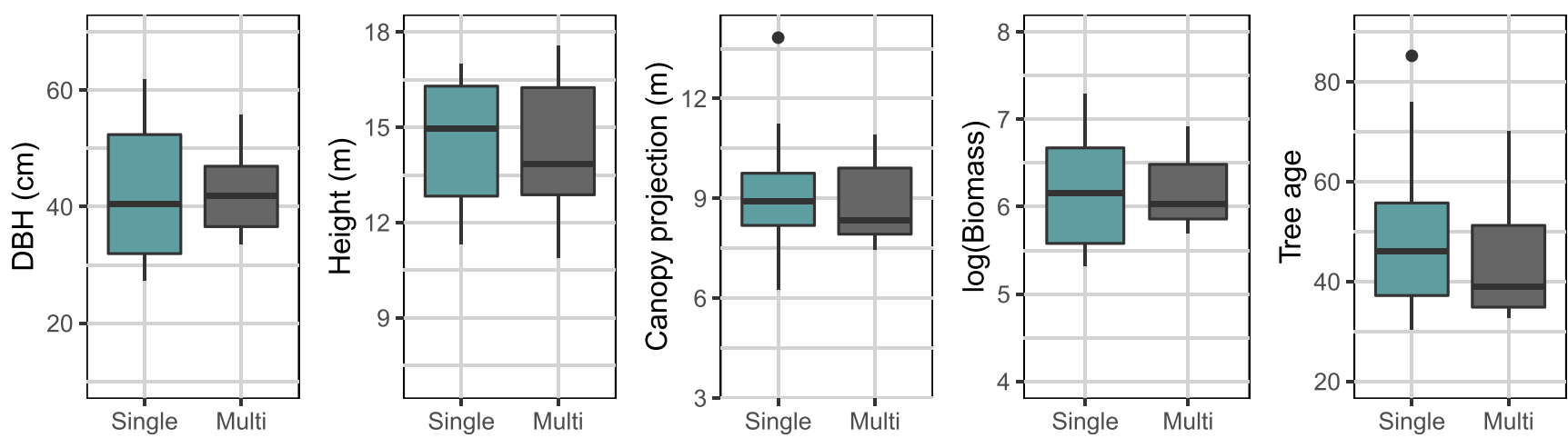

Fig. 3 DBH, height, canopy projection, biomass and tree age differences between single- and multi-stemmed trees. Mean values of each variable were calculated using the exhaustive (upper panels) and the dominant tree sampling (bottom panels). The asterisks indicate significant differences at $P<0.05$

The positive PY 1980 was linked to higher June-July SPEI-3 values and to mild temperatures during that season. The negative PY of 1991 was linked to warm temperatures during previous year's August-September. The negative climatelinked PYs 1976 and 2005 occurred in the four chronologies.

We identified similar numbers of climate-linked PYs between architectures when using the exhaustive sampling (two negative and zero positive climate-linked pointer years; Fig. 4). Five climate-linked PYs were identified for the single-stemmed trees (four negative and one positive) and two climate-linked PYs for the multi-stemmed trees (two negative and zero positive), when using the dominant sampling (Fig. 5).

\subsection{Wood density}

The LMEM revealed lower wood density in single-stemmed trees than in multi-stemmed trees for DBHs $>30 \mathrm{~cm}$. The social status had no significant effect on wood density (Fig. 6; Table 2).

\subsection{Tree growth}

The LMEMs indicated that tree-ring width decreased with age and increased with cumulative tree-ring width and higher
June-July SPEI-3 values. Tree-ring width differed between social status and architectures. Dominant trees exhibited higher tree-ring widths than non-dominant trees across the 60 first years of the life of trees. Single-stemmed trees exhibited higher tree-ring widths than multi-stemmed trees, particularly after the first 30 years (Fig. 7a, b, Table 3).

The LMEMs indicated also that BAI increased with age, but more gradually after the first 30 years. BAI also increased with higher June-July SPEI-3 values and differed between social status and architectures. Thus, dominant trees exhibited higher BAI values than non-dominant trees, particularly after the first 30 years. Multi-stemmed trees also exhibited higher BAI values than single-stemmed trees, particularly during the first 30 years (Fig. 7c, d, Table 3).

\section{Discussion}

\subsection{Growth response to climate variations between architectures and social status}

Tree growth was mainly and negatively controlled by soil water deficit from June to July of the current year and from previous year's September to October, irrespective 

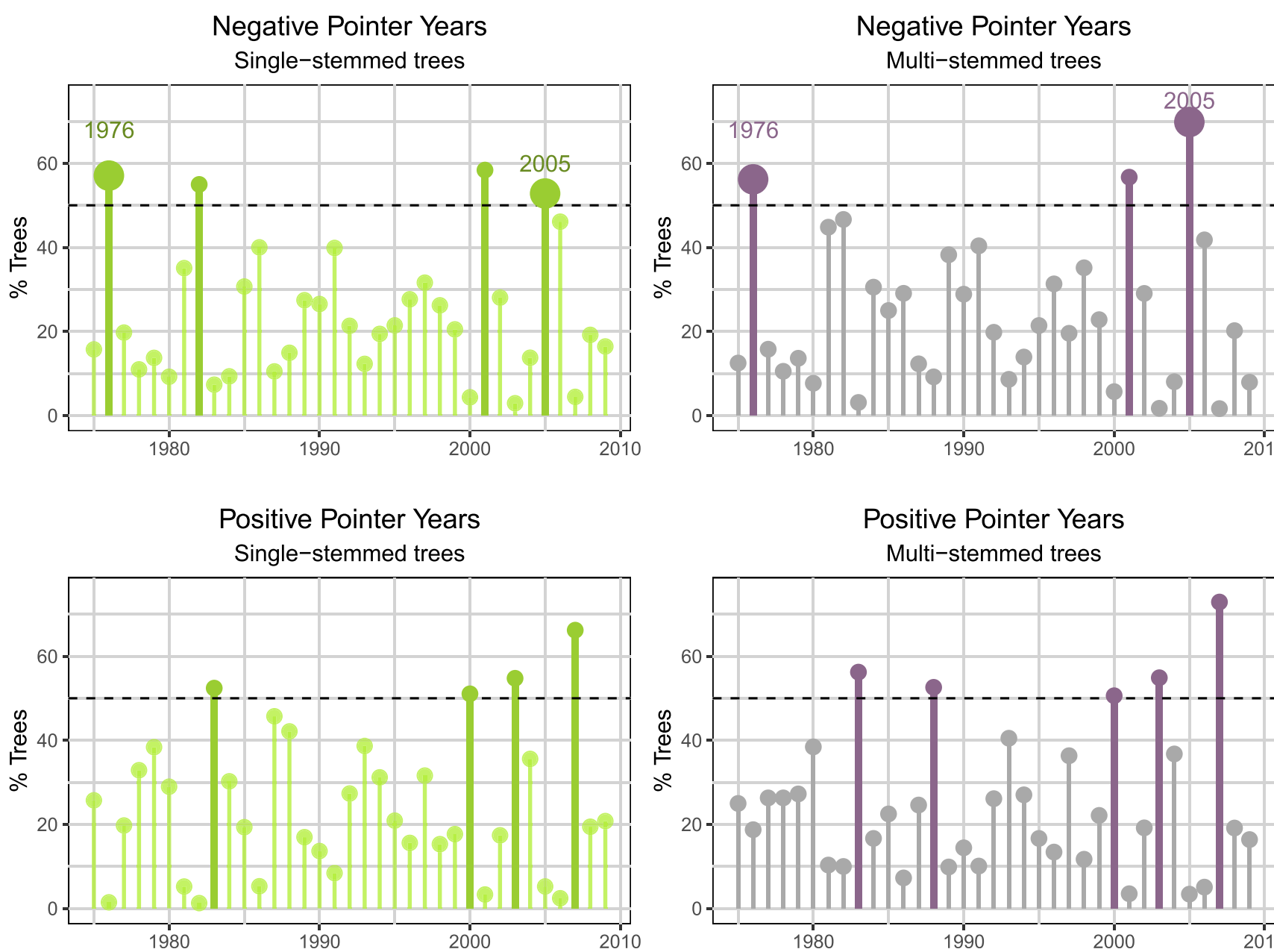

Fig. 4 Negative (upper panels) and positive (lower panels) pointer years for single- (left panels) and multi-stemmed (right panels) trees using the exhaustive tree sampling. The dashed line indicates the minimum threshold of $50 \%$ of trees within single- or multi-stemmed trees that should

of tree architecture or social status. Excessive warm temperatures during previous year's August to September exerted a negative impact on growth in the two singlestemmed chronologies and in the multi-stemmed one for the dominant sampling. The similar response to soil water deficit and temperature found in the correlations among groups can largely be attributed to the relatively low variability in the detrended tree-ring width series used for the climate-growth analyses (Nehrbass-Ahles et al. 2014), particularly within the same site. Pedunculate oak is relatively tolerant to soil water deficit owing to its deep rooting (Rosengren et al. 2006), low susceptibility to embolism (Cochard 1992) and relatively tight control of stomata conductance and photosynthesis under drought conditions (Epron and Dreyer 1993). In line with Andersson et al. (2011), we found that precipitation exerted a higher influence on oak growth than temperature, as confirmed by the nonsignificant response of growth (tree-ring width and BAI) to temperatures in the LMEMs irrespective of tree architecture or social

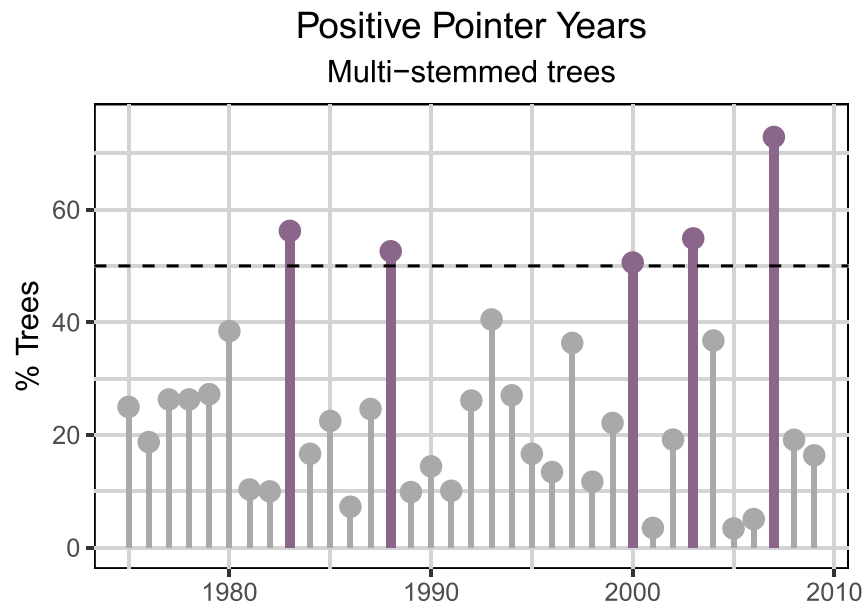

display a negative (positive) event year for a particular year to be considered as negative (positive) pointer year. Climate-linked pointer years are indicated with larger circles and a label for the year

status (Table 3). Indeed, the greater influence of precipitation during late spring and early summer in the current year on tree growth has been widely reported for other pedunculate oak stands across Europe (Bednarz and Ptak 1990; Kelly et al. 2002; Drobyshev et al. 2008; Friedrichs et al. 2008; Andersson et al. 2011; Barsoum et al. 2015).

Pointer year analysis can be an additional source of information to understand climate-growth interactions (Matisons et al. 2013). A high percentage of extremely narrow or wide tree rings in a stand is usually caused by extreme climatic events (Schweingruber et al. 1990). In general, higher numbers of pointer years have been related to higher mean climatic sensitivity (Jetschke et al. 2019). Dominant single-stemmed trees displayed the largest number of negative and positive climate-linked PYs, i.e. four negative and one positive during the period from 1975 to 2009 , indicating a relatively higher climatic sensitivity than dominant multi-stemmed trees and single and multi-stemmed trees from the overall sample. A previous study sampling only dominant trees also reported higher climatic sensitivity in single- 
Negative Pointer Years

Dominant single-stemmed trees

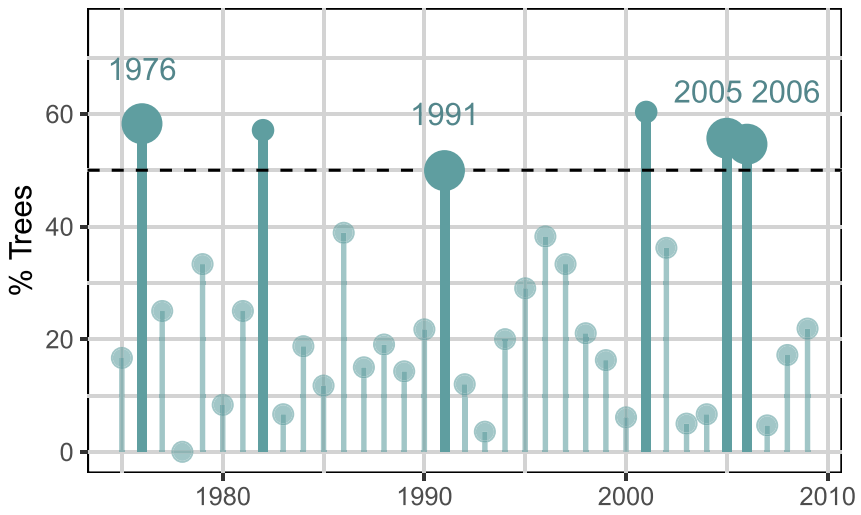

Positive Pointer Years

Dominant single-stemmed trees

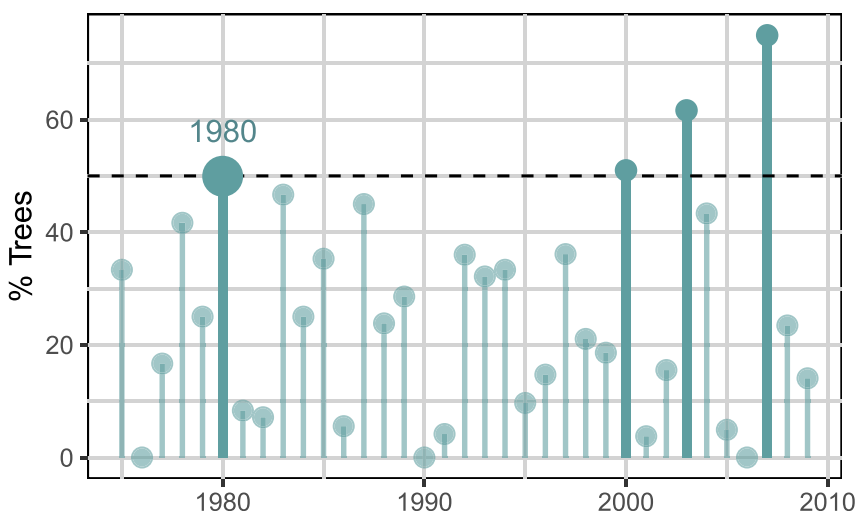

Fig. 5 Negative (upper panels) and positive (lower panels) pointer years for single- (left panels) and multi-stemmed (right panels) trees using the dominant tree sampling. The dashed line indicates the minimum threshold of $50 \%$ of trees within single- or multi-stemmed trees that should

stemmed oaks compared with multi-stemmed ones since 1975 (Stojanović et al. 2017).

In general, oak growth underlies high autocorrelation (e.g. Drobyshev et al. 2007), indicating that it is highly dependent on carbohydrate storage and consequently climate conditions
Negative Pointer Years

Dominant multi-stemmed trees

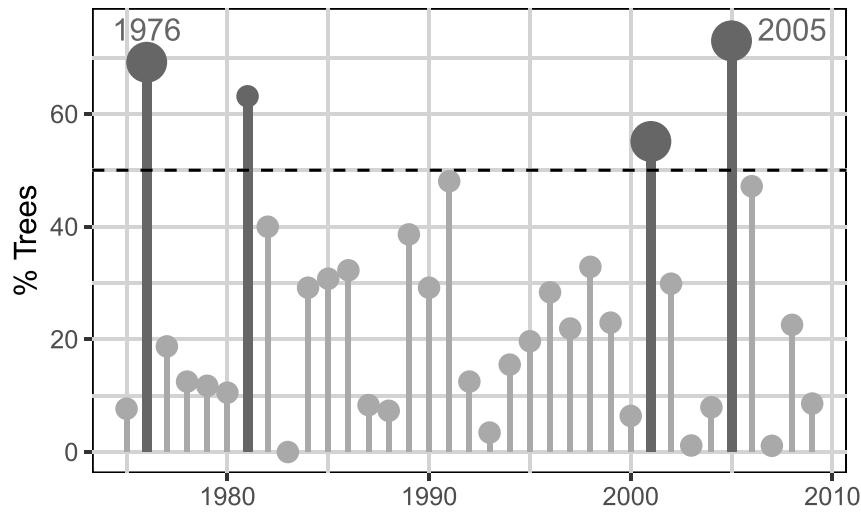

Positive Pointer Years

Dominant multi-stemmed trees

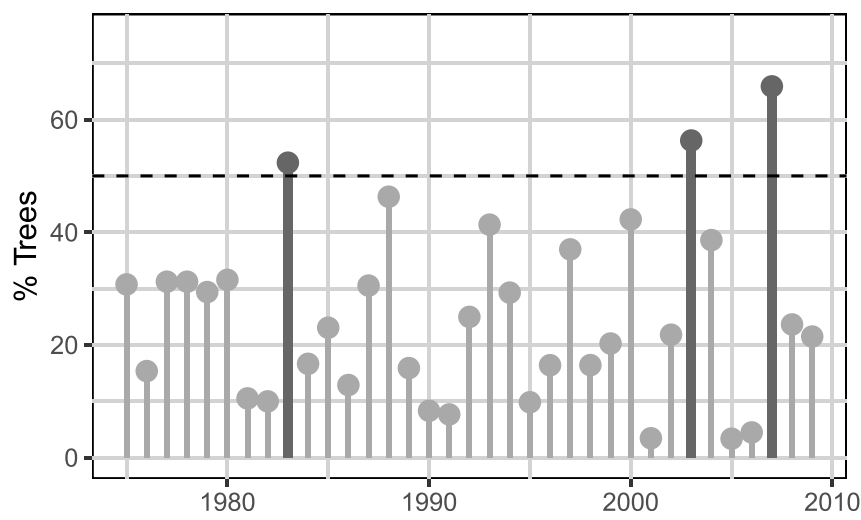

display a negative (positive) event year for a particular year to be considered as negative (positive) pointer year. Climate-linked pointer years are indicated with larger circles and a label for the year

during the previous year (Esper et al. 2015). Trees with high autocorrelation tend to buffer the effects of environmental variation on growth more efficiently than trees with lower autocorrelation (Schweingruber 1996; Zang et al. 2012). Indeed, the importance of precipitation during the previous autumn in
Fig. 6 Wood density predictions across DBH. The observed values are indicated with green and violet circles, for single- and multi-stemmed trees, respectively

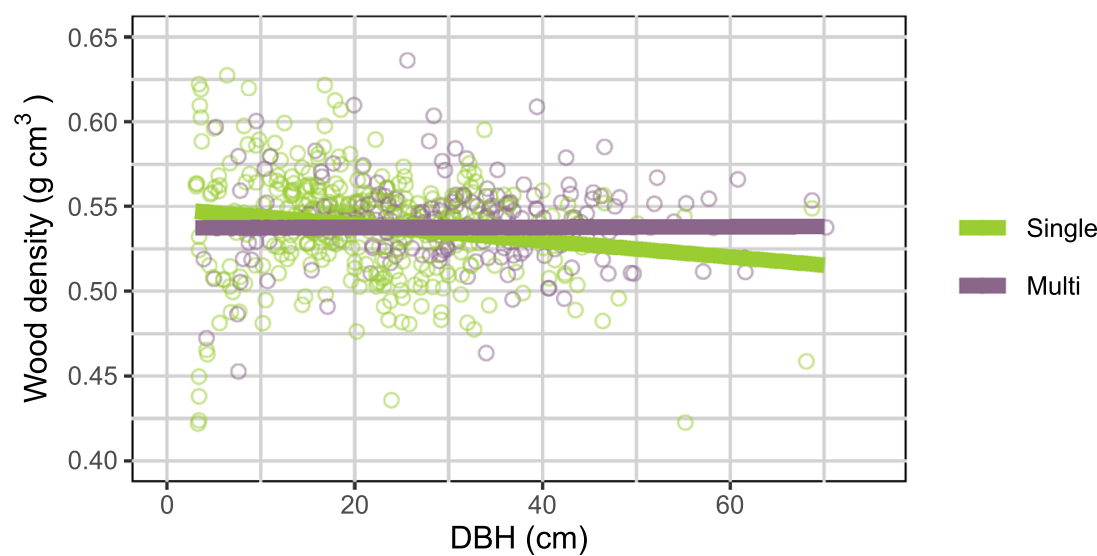

INRAC פ̂springer 
Table 2 LMEM results for wood density (WD, $\mathrm{g} \mathrm{cm}^{-3}$ ). The variable DBH was scaled in the model. TA is the tree architecture, i.e. single- or multi-stemmed trees. The level multi-stemmed trees (variable tree architecture) is included in the intercept. The $R^{2}$ due to fixed $\left(R^{2}{ }_{\mathrm{m}}\right)$ and due to fixed and random effects $\left(R^{2} \mathrm{c}\right)$ for each selected model is also provided. Significance of the $P$ values is indicated by $* * * P<0.001$ or $* P<0.05$

\begin{tabular}{lllll}
\hline & WD & & & \\
Fixed effects & Estimate & SE & $t$ & $P$ \\
Intercept & 0.538 & 0.005 & 117.561 & $* * *$ \\
TA: single & -0.001 & 0.003 & -0.221 & 0.825 \\
DBH & 0.0001 & 0.0019 & 0.079 & 0.937 \\
TA: single $\times$ DBH & -0.0062 & 0.0025 & -2.529 & $*$ \\
Random effects & SD & & & \\
Stand & 0.015 & & & \\
$R^{2}{ }_{\mathrm{m}}$ & 0.02 & & & \\
$R^{2} \mathrm{c}$ & 0.26 & & & \\
\hline
\end{tabular}

controlling growth has been previously reported (Drobyshev et al. 2008; Friedrichs et al. 2008; Andersson et al. 2011) and can be explained by an extended period of activity at the end of
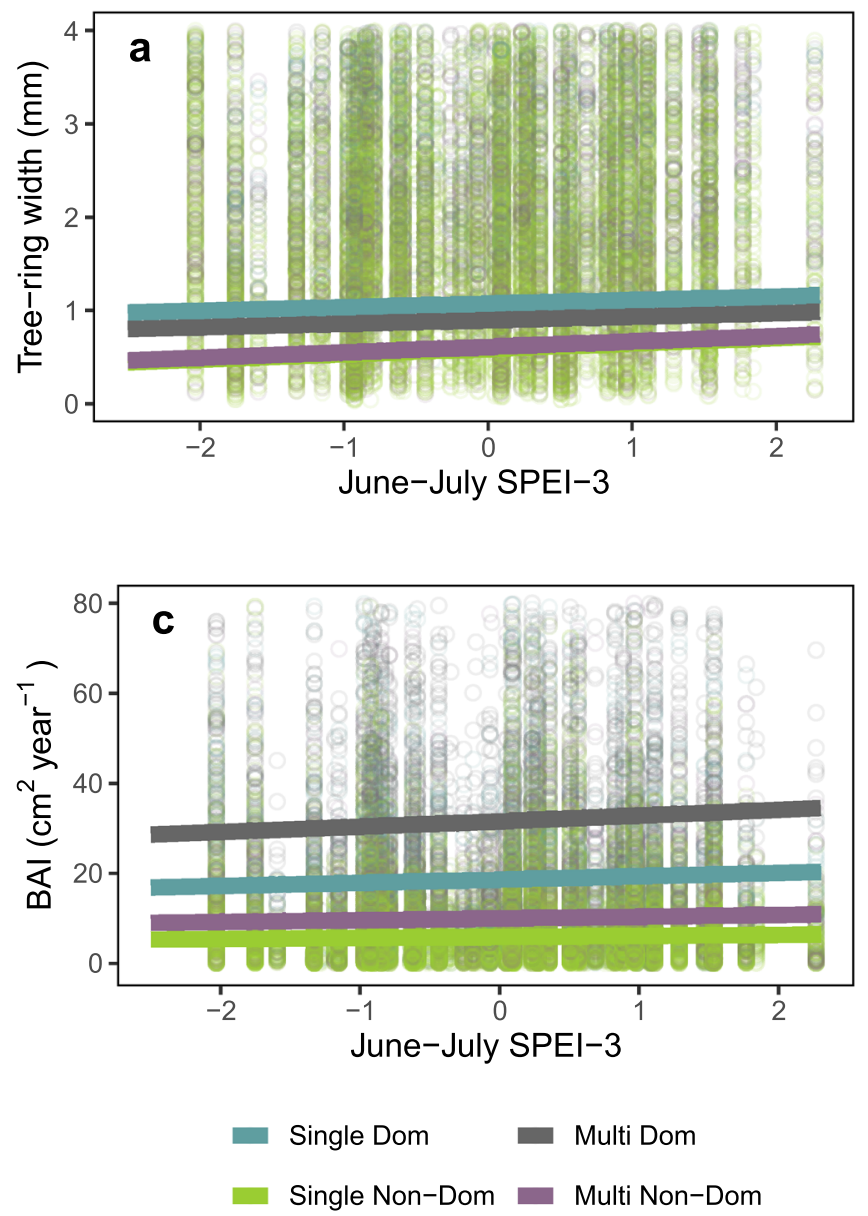

Fig. 7 Tree-ring width (RW; a, b) and basal area increment (BAI; c, d) predictions across the first 60 years of the life of the trees (ring age; $b, d$ ) and June-July SPEI-3 (a, c), for dominant and non-dominant single- or multi-stemmed trees. The observed values are indicated with green and the growing season, resulting in more carbohydrate storage for earlywood production in the following growing season (Drobyshev et al. 2008). In this study, we found that multistemmed trees displayed higher first-order autocorrelations than single-stemmed trees regardless of their social status. Accordingly, coppiced treesshouldbe displaying alowersensitivity (thatis, complacency) to the variationin externalfactors, suchas soil water deficit following severe droughts (Drobyshev et al. 2007).

Our results also showed lower mean sensitivity - defined as the 'mean percentage change from each measured yearly ring value to the next' (Douglass 1983) - for the dominant chronologies ( 0.29 for single and 0.30 for multi-stemmed trees) compared with the exhaustive ones ( 0.34 for both single- and multistemmed trees). Similar mean sensitivity values (between 0.2 and 0.3 ) have been reported in European oak monocultures representing limited climatic and/or environmental effects on tree-ring width (Barsoum et al. 2015). Thus, dominant trees may be displaying a more complacent response of growth to climate or other environmental variables on an annual timescale, as we confirmed with the higher yearly tree-ring width and BAI
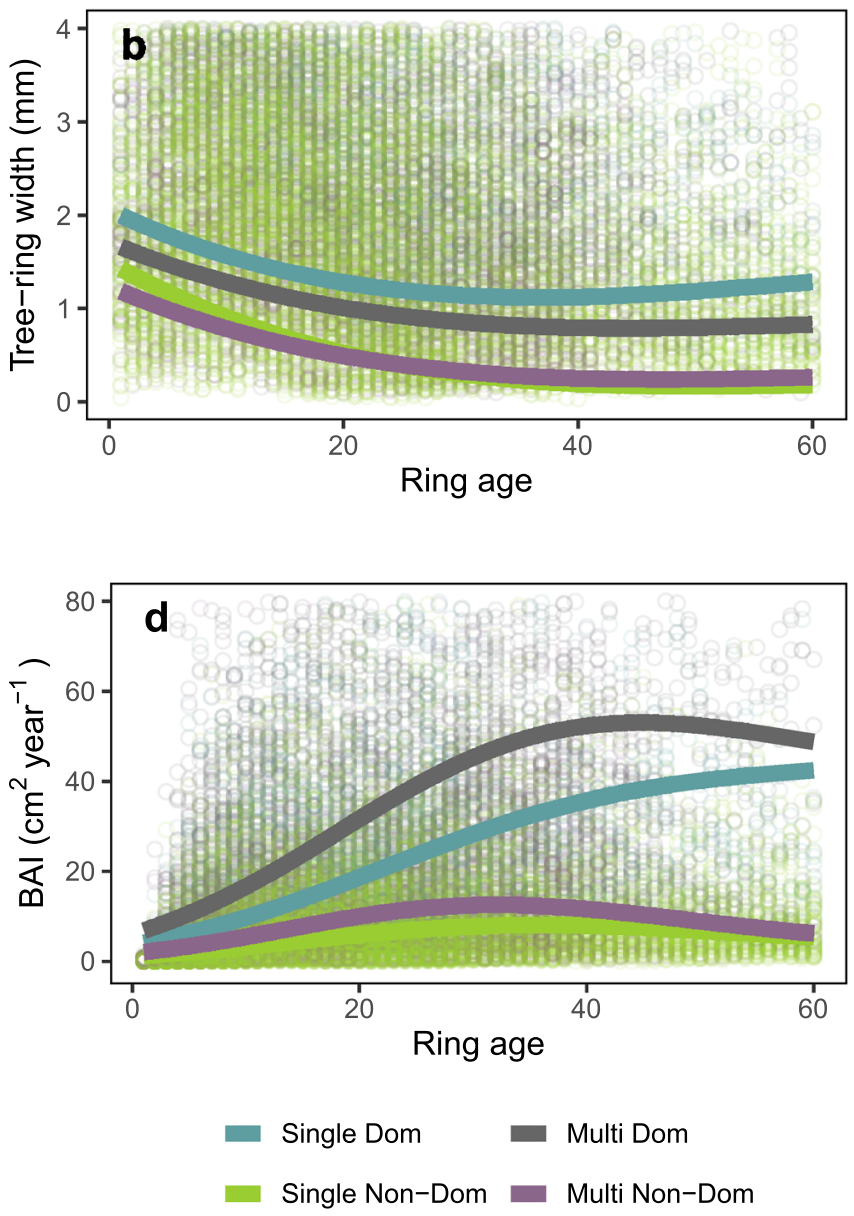

violet circles for dominant single- and multi-stemmed trees, respectively, and with blue and grey circles for non-dominant single- and multistemmed trees, respectively 
Table 3 LMEM results for tree-ring widths (RW) and basal area increments (BAI). Variables were scaled in the models. TA is the tree architecture, i.e. single- or multi-stemmed trees; ST is the social status, i.e. dominant or non-dominant tree; CRW is the cumulative tree-ring width; and RA is the ring age and refers to the year of the life of the tree. The level multi-stemmed trees (variable tree architecture) and the level nondominant (variable social status) are included in the intercept. The marginal and conditional $R^{2}$ of each selected model are also provided. Significance of the $P$ values is indicated by $* * * P<0.001 ; * * P<0.01$; or $* P<0.05$

\begin{tabular}{|c|c|c|c|c|c|c|c|c|}
\hline & RW & & & & BAI & & & \\
\hline Fixed effects & Estimate & SE & $t$ & $P$ & Estimate & SE & $t$ & $P$ \\
\hline Intercept & 1.02 & 0.05 & 19.7 & $* * *$ & 0.72 & 0.13 & 5.6 & $* * *$ \\
\hline TA: single & 0.12 & 0.05 & 2.6 & $* *$ & -0.49 & 0.09 & -5.5 & $* * *$ \\
\hline ST: dominant & 0.44 & 0.06 & 7.7 & $* * *$ & 1.20 & 0.09 & 12.8 & $* * *$ \\
\hline CRW & 0.154 & 0.006 & 24.6 & $* * *$ & & & & \\
\hline RA $<30$ years & -3.28 & 0.11 & -29.1 & $* * *$ & 3.32 & 0.09 & 36.6 & $* * *$ \\
\hline RA > 30 years & -2.40 & 0.10 & -25.2 & $* * *$ & 0.34 & 0.08 & 4.2 & $* * *$ \\
\hline June-July SPEI-3 & 0.060 & 0.005 & 11.8 & $* * *$ & 0.041 & 0.006 & 7.3 & $* * *$ \\
\hline TA: single $\times$ D: dominant & 0.20 & 0.07 & 3.0 & $* *$ & & & & \\
\hline TA: single $\times$ CRW & -0.017 & 0.006 & -2.8 & $* *$ & & & & \\
\hline $\mathrm{CRW} \times \mathrm{D}$ : dominant & -0.076 & 0.006 & -12.5 & $* * *$ & & & & \\
\hline TA: single $\times$ RA $<30$ years & -0.04 & 0.12 & -0.4 & 0.724 & 0.02 & 0.10 & 0.2 & 0.829 \\
\hline TA: single $\times$ RA $>30$ years & 0.23 & 0.10 & 2.3 & $*$ & 0.40 & 0.08 & 5.0 & $* * *$ \\
\hline ST: dominant $\times$ RA $<30$ years & 0.80 & 0.14 & 5.7 & $* * *$ & 0.13 & 0.11 & 1.2 & 0.234 \\
\hline ST: dominant $\times$ RA $>30$ years & 0.82 & 0.10 & 8.0 & $* * *$ & 0.95 & 0.08 & 12.4 & $* * *$ \\
\hline ST: dominant $\times$ June-July SPEI-3 & -0.021 & 0.010 & -2.2 & $*$ & & & & \\
\hline Random effects & SD & & & & $\mathrm{SD}$ & & & \\
\hline Stand & 0.11 & & & & 0.37 & & & \\
\hline Tree & 0.30 & & & & 0.84 & & & \\
\hline$R_{\mathrm{m}}^{2}$ & 0.35 & & & & 0.35 & & & \\
\hline$R^{2} \mathrm{c}$ & 0.50 & & & & 0.73 & & & \\
\hline
\end{tabular}

values found in the dominant trees and the significant negative interaction for dominant trees with June-July SPEI-3 (Table 3, Fig. 7c). This result is in line with the study of Zang et al. (2012) who found a lower limitation of tree growth under harsher climatic conditions in large trees than in small ones.

\subsection{Wood density variations between architectures and social status}

Wood density was significantly lower for single-stemmed trees for DBHs larger than $30 \mathrm{~cm}$ irrespective of social status. Wood density is a pivotal functional trait that influences the mechanical stability of trees (Anten and Schieving 2010) as well as their vulnerability to drought (Hacke et al. 2001). A lower wood density implies a higher risk of drought-induced cavitation, especially in ring-porous species such as oaks (Hacke et al. 2001; Eilmann et al. 2014). It is commonly associated with faster growth and has been reported to be decreasing in various European trees (Mausolf et al. 2018; Pretzsch et al. 2018; Alfaro-Sánchez et al. 2019). In our study, the observed lower wood density of the smaller single-stemmed trees was in line with the consistently higher growth (tree-ring width) reported for that group compared with multi-stemmed trees (Figs. 6 and 7b). Considering that the pre-established root system of coppiced trees can significantly improve water and nutrient availability (Zhu et al. 2012; Pemán et al. 2017), multi-stemmed trees may be displaying lower wood density and higher growth soon after resprouting probably due the ecophysiological benefits they have at early stages compared with trees growing up from seeds, i.e. improved water status and carbon fixation during summer in resprouts compared with mature plant shoots (Castell et al. 1994). Thus, at certain ages, coppiced trees increase their wood density and reduce their growth rate probably owing to the competition among resprouts (Castell and Terradas 1995).

\subsection{Growth variations according to social status and tree architecture}

In general, annual growth rates in oaks have been shown to decrease rapidly after the first 20 years of growth and to stabilise at an age of 40-60 years (Espelta et al. 1999; Haneca et al. 2005). Here, dominant single-stemmed trees displayed higher growth than dominant multi-stemmed trees when comparing the growth peryear(tree-ring width) of the cored stem, possibly driven by the intra-tree competition of multi-stemmed trees (Mayor and Rodà 1993; Castell and Terradas 1995; Montes etal.2004). In contrast, when using theBAI corrected formultiplestems pertree, dominantmulti-stemmed trees overtake dominant single-stemmed ones in growth per year during 
the first 60 years of life (Fig. 7). However, BAI starts to slowly decrease after an age of 30 years both for dominant multistemmed trees and for non-dominant ones (either single- or multistemmed), whereas for dominant single-stemmed trees, BAI was still increasing at the end of the study period (Fig. 7d).

Differences were also found for growth between architectures for each of the sampling designs (Pemán et al. 2017; Stojanović et al. 2017). Higher BAI values for dominant coppiced holm oak trees are probably associated to lower water limitation of multistemmed oaks to face drought conditions, owing to the benefits of a larger and deeper pre-established root system (Pemán et al. 2017; Stojanović et al. 2017), although the advantage of coppiced vs high forests might decrease with time as the multiple stems grow up (Stojanović et al. 2016). Thus, the decrease of BAI in dominant multi-stemmed trees can be associated to the progressive increase in intra-individual competition among stems and the replenishment of belowground structures after the resources spent in the resprouting process (Espelta et al. 1999; Cotillas et al. 2016).

\subsection{Considerations on the sampling design: dominant vs exhaustive}

When studying growth patterns in unmanaged second-growth forests, such as the pedunculate forests from SW France, the high variation of tree growth caused by the heterogeneous distribution of tree sizes and age classes may complicate the identification of the most adapted individuals to face extreme climatic events. Indeed, our results showed that tree growth in the investigated stands differed with social status. These results are in line with those of Nehrbass-Ahles et al. (2014), suggesting that the sampling design strongly affects the quantification of growth trends using BAI and tree-ring width values.

Conclusions from dendroecological studies should be restricted to the type of trees sampled in order to avoid bias in the assessment of climate sensitivity or inappropriate estimation of growth trends and carbon storage, particularly when only dominant trees are studied (Sullivan and Csank 2016). As for other species, tree growth has been reported to increase in pedunculate oaks that have well-developed crowns (Drobyshev et al. 2007) because of their higher efficiency in light harvesting and photosynthetic performance (Niinemets 2010). Thus, our results pointed out that using an exhaustive sampling tends to buffer the differences between architectures reported in growth per year (tree-ring width values), BAI and climate sensitivity, as differences were more evident when using dominant trees.

\section{Conclusion: implications for spontaneous oak forest management and conservation}

Ongoing regional climate change could severely slow down and ultimately impair the vigorous expansion of pedunculate oak across theLandesdeGascognein the coming decades(Urlietal.2015).Itis challenging to propose conservation measures for spontaneously established oak forest stands that are typically characterised by the absence of any systematic management or exploitation.

Dominant trees potentially play a three-fold role in the stands. First, they contribute most to biomass allocation and therefore to carbon storage (in our study area, dominant trees accounted more than two-thirds of the total biomass per stand). Secondly, they can facilitate the survival of smaller trees in their surroundings (Gómez-Aparicio et al. 2004; Miriti 2006); and lastly, they contribute most to enhancing reproduction and recruitment (Lloret et al. 2012; Gerzabek et al. 2017). Management options that preserve large (dominant) trees may reduce future climate hazards and ensure the ecosystem services that these second-growth pedunculate oak forests are providing. Particular attention should be paid to preserve dominant multi-stemmed trees, because this architecture tends to imply a greater allocation of biomass, a higher BAI per year, and lower sensitivity to climate extremes and therefore they may be more adapted to future drought episodes than dominant single-stemmed trees.

Multi-stemmed individuals should be conserved especially in the early stages of forest establishment when stands are still limited to a few dozens or scores of (mostly small) trees. On the contrary, we do not consider systematic coppicing of entire stands a suited management option because it would result in more even-sized stands and drought episodes could be particularly pernicious when they occur shortly after the coppicing. As a matter of fact, it might be precisely the lack of a systematic forest and vegetation management what could enable spontaneous oak forest stands to maximise their ability to cope with an increasingly harsher climate drawing on their natural regeneration potential (Lloret et al. 2012).

Acknowledgements We thank Yannick Mellerin, Frédéric Lagane, Inge van Halder, Bastien Castagneyrol, Fabrice Vetillard and Elias Garrouj for their help with the field work and Laura Fuentes for her assistance during the wood density measurements.

Contributions of the co-authors $\mathrm{AH}$ and $\mathrm{DB}$ conceived and designed the research. EVC and DB collected the wood samples and the field data. DB obtained the tree-ring data. RAS led the analysis and wrote the manuscript, with major contributions by JME and AH. All co-authors were involved in revising and editing the manuscript. All authors read and approved the final manuscript.

Funding information This study was funded by the project NEWFORLAND (RTI2018-099397-C22) of the Spanish Ministry of Economy, Industry and Competitiveness, and by the BiodivERsA project SPONFOREST (BiodivERsA3-2015-58). RAS is supported by the postdoctoral grant Juan de la Cierva-Formación-FJCI-2015-26848.

Data availability The dataset used in the current study is available in the figshare repository: https://doi.org/10.6084/m9.figshare.11982471

\section{Compliance with ethical standards}

Conflict of interest The authors declare that they have no conflict of interest. 


\section{Appendix}

Table 4 Stand characteristics

\begin{tabular}{|c|c|c|c|c|c|c|c|c|c|c|}
\hline \multirow[t]{2}{*}{ Stand } & \multicolumn{2}{|c|}{ DBH $(\mathrm{cm})$} & \multicolumn{2}{|c|}{ Height (m) } & \multicolumn{2}{|c|}{ Canopy projection (m) } & \multicolumn{2}{|c|}{ Biomass $\left(\mathrm{Kg}\right.$ tree $\left.{ }^{-1}\right)$} & \multirow[t]{2}{*}{$\%$ multi-stemmed trees } & \multirow[t]{2}{*}{ Tree density $\left(\right.$ trees ha $\left.{ }^{-1}\right)$} \\
\hline & Mean & SD & Mean & $\mathrm{SD}$ & Mean & SD & Mean & $\mathrm{SD}$ & & \\
\hline A & 19 & 9 & 11 & 3 & 5.4 & 2.3 & 94 & 116 & 25.3 & 470 \\
\hline B & 23 & 22 & 8 & 4 & 6 & 3 & 276 & 905 & 25.0 & 267 \\
\hline $\mathrm{C}$ & 26 & 9 & 9 & 2 & 5.8 & 1.6 & 136 & 133 & 21.2 & 486 \\
\hline $\mathrm{D}$ & 35 & 16 & 15 & 4 & 7 & 3 & 439 & 457 & 21.7 & 295 \\
\hline $\mathrm{E}$ & 22 & 17 & 10 & 5 & 6 & 3 & 199 & 298 & 37.0 & 323 \\
\hline $\mathrm{F}$ & 19 & 10 & 8 & 3 & 5.5 & 2.2 & 81 & 131 & 100.0 & 356 \\
\hline G & 37 & 10 & 13 & 3 & 6.8 & 1.5 & 356 & 238 & 65.6 & 92 \\
\hline $\mathrm{H}$ & 22 & 11 & 11 & 4 & 6.1 & 2.5 & 124 & 113 & 50.9 & 253 \\
\hline I & 24 & 9 & 13 & 4 & 6.0 & 1.9 & 170 & 168 & 55.4 & 241 \\
\hline K & 31 & 14 & 11 & 2 & 6 & 3 & 238 & 260 & 17.4 & 330 \\
\hline $\mathrm{L}$ & 21 & 12 & 9 & 4 & 5 & 3 & 115 & 145 & 18.8 & 2302 \\
\hline $\mathrm{M}$ & 21 & 15 & 10 & 4 & 6 & 3 & 149 & 196 & 27.1 & 143 \\
\hline $\mathrm{O}$ & 25 & 13 & 11 & 4 & 6.8 & 2.4 & 176 & 219 & 15.4 & 273 \\
\hline $\mathrm{P}$ & 25 & 19 & 9 & 4 & 7 & 4 & 234 & 371 & 26.7 & 241 \\
\hline Q & 31 & 16 & 13 & 3 & 7 & 3 & 308 & 409 & 20.8 & 142 \\
\hline
\end{tabular}

SPEI 3

Single-stemmed trees

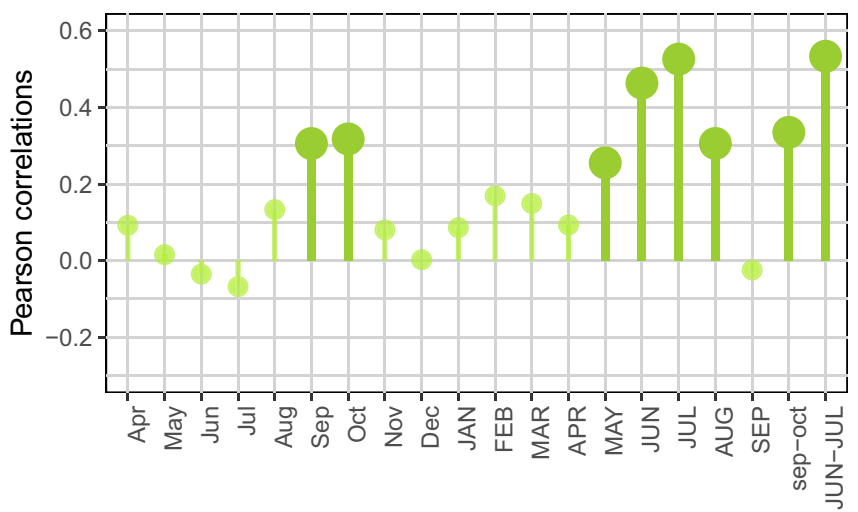

TEMPERATURE

Single-stemmed trees

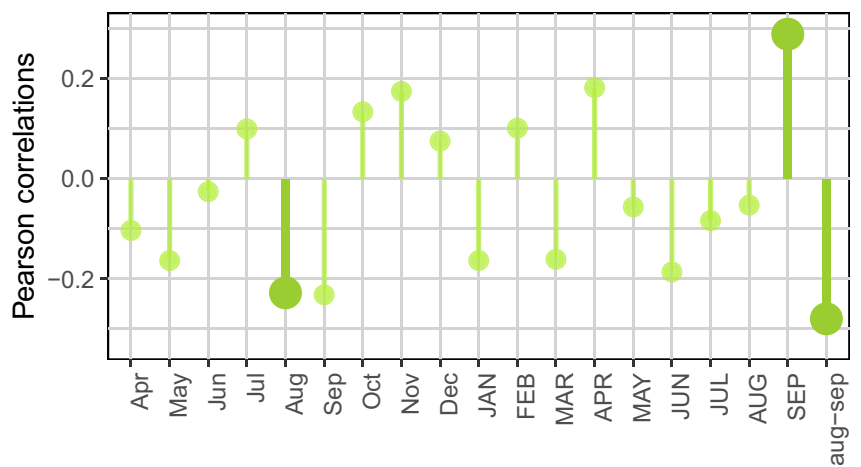

SPEI 3

Multi-stemmed trees

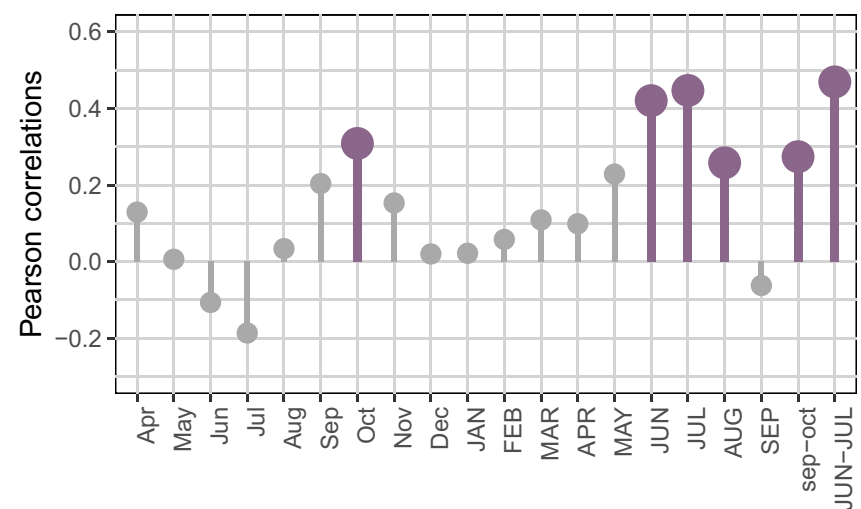

TEMPERATURE

Multi-stemmed trees

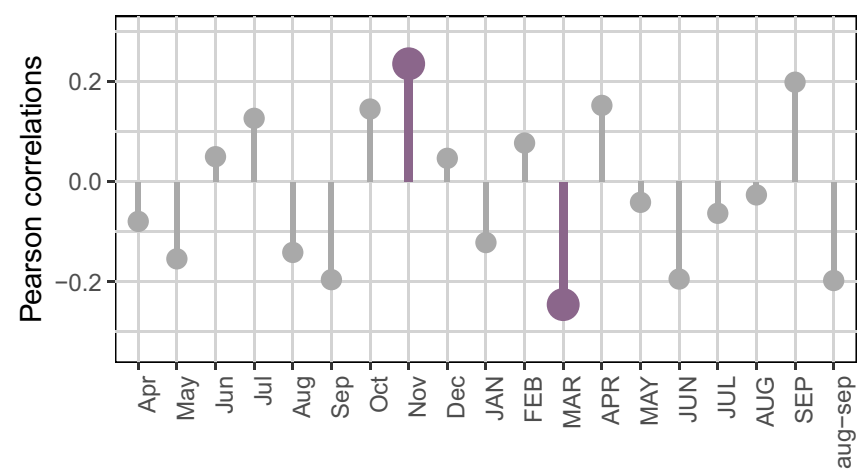

Fig. 8 Climate-growth analyses for single- and multi-stemmed trees for the exhaustive sampling 
SPEI 3

Dominant single-stemmed trees

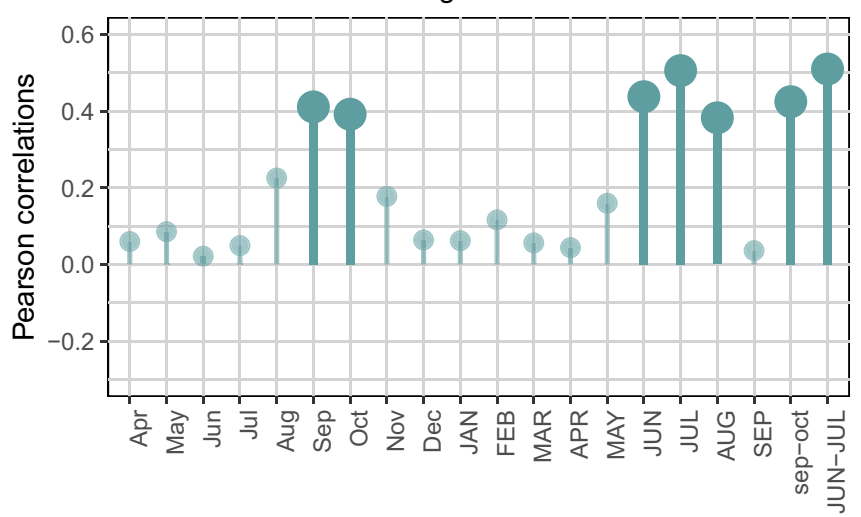

TEMPERATURE

Dominant single-stemmed trees

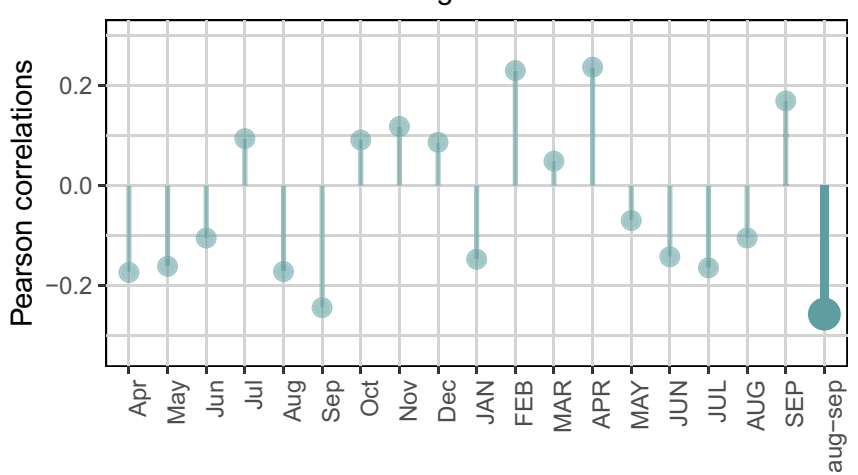

SPEI 3

Dominant multi-stemmed trees

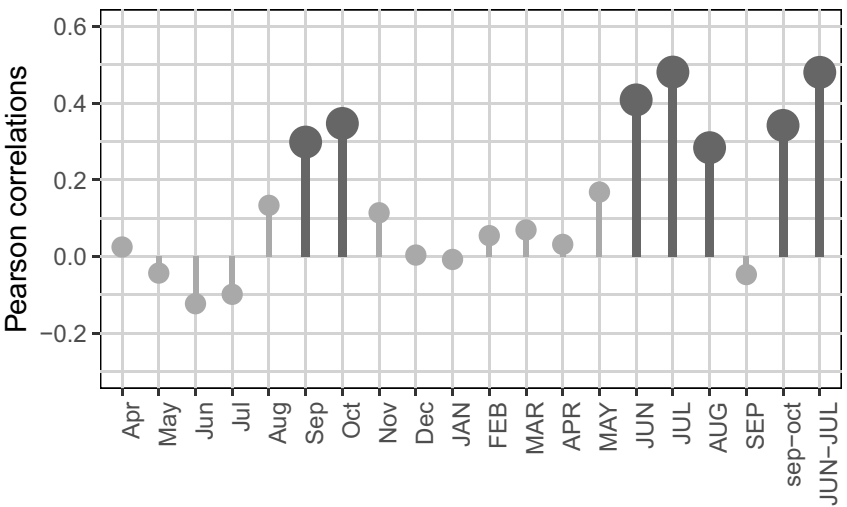

TEMPERATURE

Dominant multi-stemmed trees

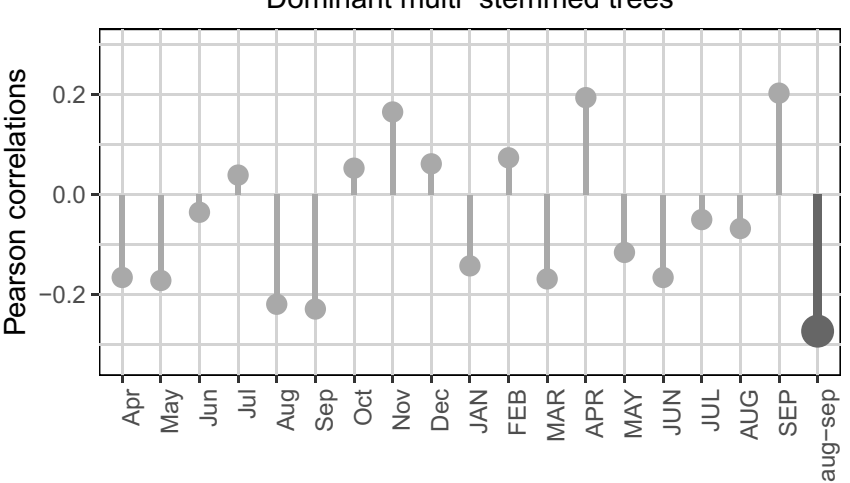

Fig. 9 Climate-growth analyses for single- and multi-stemmed trees for the dominant trees 

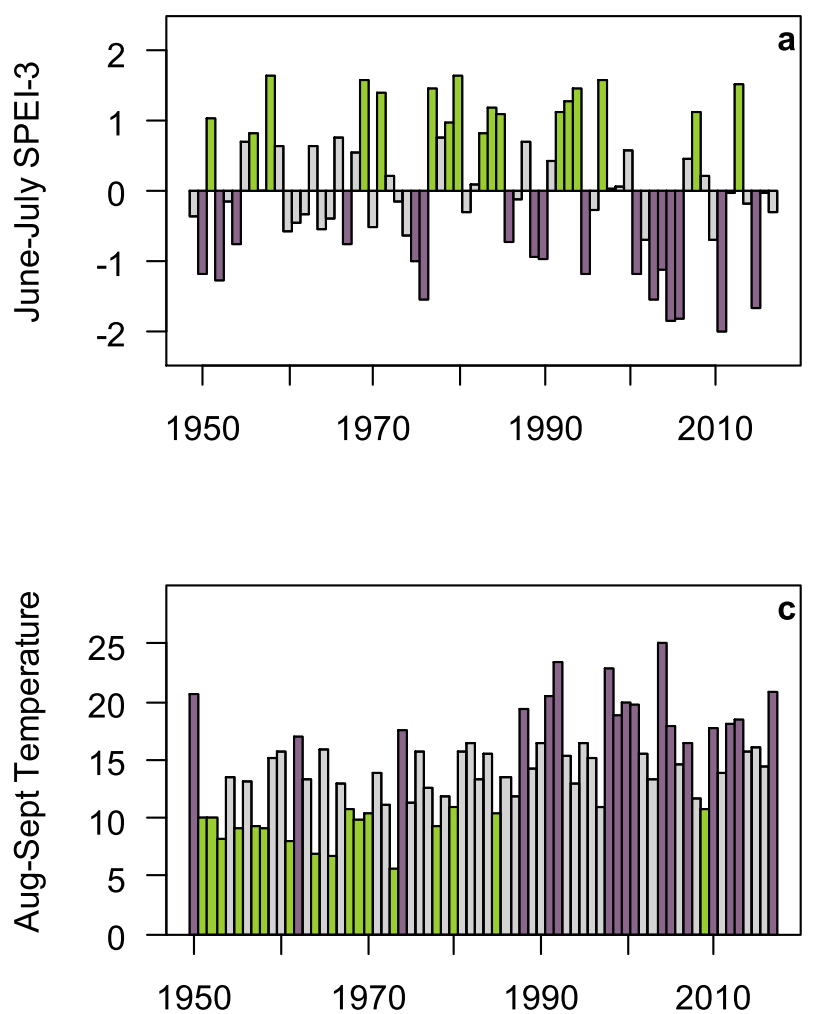

Fig. 10 June-July SPEI-3 (a) and August-September temperature (c) time series for the period 1949-2017. Green (violet) bars indicate extremely wet and cool (extremely dry and warm) years, as those with June-July SPEI-3 or August-September temperatures values above or below the 75 th and 25 th percentile of the climate time series, respectively.

\section{References}

Alfaro-Sánchez R, Jump AS, Pino J et al (2019) Land use legacies drive higher growth, lower wood density and enhanced climatic sensitivity in recently established forests. Agric For Meteorol 276-277: 107630. https://doi.org/10.1016/j.agrformet.2019.107630

Alfaro-Sánchez R, Valdés-Correcher E, Espelta JM, Hampe A, Bert D (2020) How do social status and tree architecture influence radial growth, wood density and drought response in spontaneously established oak forests? V1. Figshare [Dataset] https://doi.org/10. 6084/m9.figshare. 11982471

Allen CD, Macalady AK, Chenchouni $\mathrm{H}$ et al (2010) A global overview of drought and heat-induced tree mortality reveals emerging climate change risks for forests. For Ecol Manag 259:660-684. https://doi. org/10.1016/j.foreco.2009.09.001

Andersson M, Milberg P, Bergman K-O (2011) Low pre-death growth rates of oak (Quercus robur L.) - is oak death a long-term process induced by dry years? Ann For Sci 68:159-168. https://doi.org/10. 1007/s13595-011-0017-y

Anten NPR, Schieving F (2010) The role of wood mass density and mechanical constraints in the economy of tree architecture. Am Nat 175:250-260. https://doi.org/10.1086/649581

Augusto L, Meredieu C, Bert D et al (2008) Improving models of forest nutrient export with equations that predict the nutrient concentration of tree compartments. Ann For Sci 65:808-808. https://doi.org/10. 1051/forest:2008059
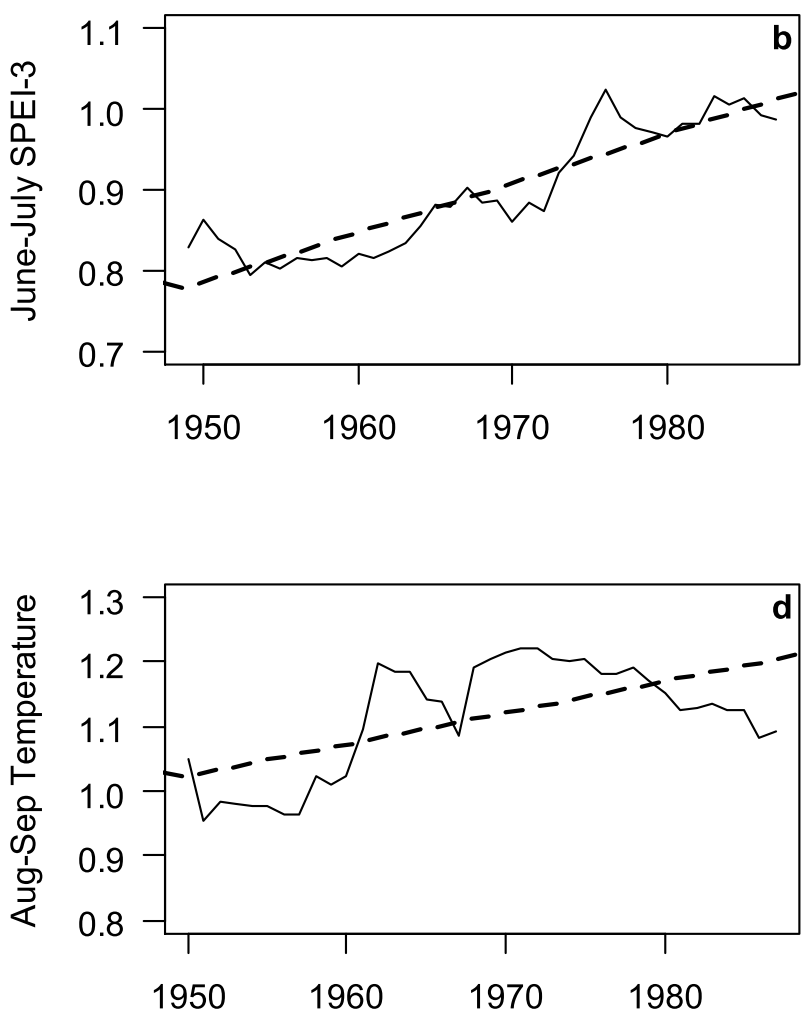

Thirty-one-year running variation for June-July SPEI-3 (b) and AugustSeptember temperatures (d) based on climate data from Mérignac climate station (Météo-France data retrieved from the INRA CLIMATIK database) for the period 1949-2017. Dashed lines represent the trend obtained in linear regression models in (b) and (d)

Baddeley A, Rubak E, Turner R (2015) Spatial point patterns: methodology and applications with R. Chapman and Hall/CRC Press, London

Balboa-Murias MA, Rojo A, Álvarez JG, Merino A (2006) Carbon and nutrient stocks in mature Quercus robur L. stands in NW Spain. Ann For Sci 63:557-565. https://doi.org/10.1051/forest:2006038

Barbaro L, Rossi J-P, Vetillard F et al (2007) The spatial distribution of birds and carabid beetles in pine plantation forests: the role of landscape composition and structure. J Biogeogr 34:652-664. https:// doi.org/10.1111/j.1365-2699.2006.01656.x

Barsoum N, Eaton EL, Levanič T, Pargade J, Bonnart X, Morison JIL (2015) Climatic drivers of oak growth over the past one hundred years in mixed and monoculture stands in southern England and northern France. Eur J For Res 134:33-51. https://doi.org/10.1007/ s10342-014-0831-5

Barton K (2018) MuMIn: multi-model inference

Bates D, Mächler M, Bolker B, Walker S (2015) Fitting linear mixedeffects models using lme4. Journal of Statistical Software 67:. https://doi.org/10.18637/jss.v067.i01

Bednarz Z, Ptak J (1990) The influence of temperature and precipitation on ring widths of oak (Quercus robur L.) in the Niepołomice Forest near Cracow, southern Poland

Bontemps J-D, Gelhaye P, Nepveu G, Hervé J-C (2013) When tree rings behave like foam: moderate historical decrease in the mean ring density of common beech paralleling a strong historical growth increase. Ann For Sci 70:329-343. https://doi.org/10.1007/s13595013-0263-2 
Bunn AG (2008) A dendrochronology program library in R (dplR). Dendrochronologia 26:115-124. https://doi.org/10.1016/j.dendro. 2008.01.002

Castell C, Terradas J (1995) Water relations, gas exchange and growth of dominant and suppressed shoots of Arbutus unedo L. Tree Physiol 15:405-409. https://doi.org/10.1093/treephys/15.6.405

Castell C, Terradas J, Tenhunen JD (1994) Water relations, gas exchange, and growth of resprouts and mature plant shoots of Arbutus unedo L. and Quercus ilex L. Oecologia 98:201-211. https://doi.org/10. 1007/BF00341473

Cherubini P, Dobbertin M, Innes JL (1998) Potential sampling bias in long-term forest growth trends reconstructed from tree rings: a case study from the Italian Alps. For Ecol Manag 109:103-118. https:// doi.org/10.1016/S0378-1127(98)00242-4

Cochard H (1992) Vulnerability of several conifers to air embolism. Tree Physiol 11:73-83. https://doi.org/10.1093/treephys/11.1.73

Colin A, Meredieu C, Labbe T, Belouard T (2010) Etude rétrospective et mise à jour de la ressource en pin maritime du massif des Landes de Gascogne après la tempête Klaus du 24 janvier 2009. Convention MAAP / IFN n ${ }^{\circ}$ E18 /2010

Cook ER, Kairiukstis LA (eds) (1990) Methods of dendrochronology. Springer Netherlands, Dordrecht

Cotillas M, Espelta J, Sánchez-Costa E, Sabaté S (2016) Aboveground and belowground biomass allocation patterns in two Mediterranean oaks with contrasting leaf habit: an insight into carbon stock in young oak coppices. Eur J For Res 135:243-252

Cotillas M, Sabaté S, Gracia C, Espelta JM (2009) Growth response of mixed Mediterranean oak coppices to rainfall reduction. For Ecol Manag 258:1677-1683. https://doi.org/10.1016/j.foreco.2009.07. 033

Cropper JP (1979) Tree-ring skeleton plotting by computer. Tree-Ring Bull 13

Cruz-Alonso V, Ruiz-Benito P, Villar-Salvador P, Rey-Benayas JM (2019) Long-term recovery of multifunctionality in Mediterranean forests depends on restoration strategy and forest type. J Appl Ecol 56:745-757. https://doi.org/10.1111/1365-2664.13340

Douglass AE (1983) Climatic cycles and tree-growth: a study of the annual rings of trees in relation to climate and solar activity. Carnegie Institution of Washington, Washington

Drobyshev I, Linderson H, Sonesson K (2007) Relationship between crown condition and tree diameter growth in southern Swedish oaks. Environ Monit Assess 128:61-73. https://doi.org/10.1007/s10661006-9415-2

Drobyshev I, Niklasson M, Eggertsson O et al (2008) Influence of annual weather on growth of pedunculate oak in southern Sweden. Ann For Sci 65:512-512. https://doi.org/10.1051/forest:2008033

Dulaurent A-M, Porté AJ, van Halder I et al (2012) Hide and seek in forests: colonization by the pine processionary moth is impeded by the presence of nonhost trees. Agric For Entomol 14:19-27. https:// doi.org/10.1111/j.1461-9563.2011.00549.x

Eilmann B, Sterck F, Wegner L, de Vries SM, von Arx G, Mohren GM, den Ouden J, Sass-Klaassen U (2014) Wood structural differences between northern and southern beech provenances growing at a moderate site. Tree Physiol 34:882-893. https://doi.org/10.1093/ treephys/tpu069

Epron D, Dreyer E (1993) Long-term effects of drought on photosynthesis of adult oak trees [Quercus petraea (Matt.) Liebl. and Quercus robur L.] in a natural stand. New Phytol 125:381-389. https://doi. org/10.1111/j.1469-8137.1993.tb03890.x

Espelta JM, Sabaté S, Retana J (1999) Resprouting dynamics. In: Ecology of Mediterranean evergreen oak forests. Springer, Berlin, pp 61-73

Esper J, Schneider L, Smerdon JE et al (2015) Signals and memory in tree-ring width and density data. Dendrochronologia 35:62-70. https://doi.org/10.1016/j.dendro.2015.07.001
Fedorová B, Kadavý J, Adamec Z et al (2018) Effect of thinning and reduced throughfall in young coppice dominated by Quercus petraea (Matt.) Liebl. and Carpinus betulus L. Aust J For Sci 135:1-17

Friedrichs DA, Buntgen U, Frank DC et al (2008) Complex climate controls on 20th century oak growth in central-west Germany. Tree Physiol 29:39-51. https://doi.org/10.1093/treephys/tpn003

Fritts HC (1976) Tree rings and climate, academic press. Elsevier, London

Gerzabek G, Oddou-Muratorio S, Hampe A (2017) Temporal change and determinants of maternal reproductive success in an expanding oak forest stand. J Ecol 105:39-48. https://doi.org/10.1111/1365-2745. 12677

Gómez-Aparicio L, Zamora R, Gómez JM et al (2004) Applying plant facilitation to forest restoration: a meta-analysis of the use of shrubs as nurse plants. Ecol Appl 14:1128-1138. https://doi.org/10.1890/ 03-5084

Greenwood S, Ruiz-Benito P, Martínez-Vilalta J, Lloret F, Kitzberger T, Allen CD, Fensham R, Laughlin DC, Kattge J, Bönisch G, Kraft NJ, Jump AS (2017) Tree mortality across biomes is promoted by drought intensity, lower wood density and higher specific leaf area. Ecol Lett 20:539-553. https://doi.org/10.1111/ele.12748

Hacke UG, Sperry JS, Pockman WT, Davis SD, McCulloh K (2001) Trends in wood density and structure are linked to prevention of xylem implosion by negative pressure. Oecologia 126:457-461. https://doi.org/10.1007/s004420100628

Haneca K, Van Acker J, Beeckman H (2005) Growth trends reveal the forest structure during Roman and Medieval times in Western Europe: a comparison between archaeological and actual oak ring series (Quercus robur and Quercus petraea). Ann For Sci 62:797805. https://doi.org/10.1051/forest:2005085

Hautdidier B, Banos V, Deuffic P, Sergent A (2018) 'Leopards' under the pines: an account of continuity and change in the integration of forest land-uses in Landes de Gascogne, France. Land Use Policy 79:990-1000. https://doi.org/10.1016/j.landusepol.2016.04.026

Jetschke G, van der Maaten E, van der Maaten-Theunissen M (2019) Towards the extremes: a critical analysis of pointer year detection methods. Dendrochronologia 53:55-62. https://doi.org/10.1016/j. dendro.2018.11.004

Kelly PM, Leuschner HH, Briffa KR, Harris IC (2002) The climatic interpretation of pan-European signature years in oak ring-width series. The Holocene 12:689-694. https://doi.org/10.1191/ $0959683602 \mathrm{hl} 582 \mathrm{rp}$

Lebourgeois F, Eberlé P, Mérian P, Seynave I (2014) Social statusmediated tree-ring responses to climate of Abies alba and Fagus sylvatica shift in importance with increasing stand basal area. For Ecol Manag 328:209-218. https://doi.org/10.1016/j.foreco.2014.05. 038

Lloret F, Escudero A, Iriondo JM et al (2012) Extreme climatic events and vegetation: the role of stabilizing processes. Glob Chang Biol 18: 797-805. https://doi.org/10.1111/j.1365-2486.2011.02624.x

Matisons R, Elferts D, Brūmelis G (2013) Pointer years in tree-ring width and earlywood-vessel area time series of Quercus robur-relation with climate factors near its northern distribution limit. Dendrochronologia 31:129-139. https://doi.org/10.1016/j.dendro. 2012.10.001

Mausolf K, Härdtle W, Jansen K, Delory BM, Hertel D, Leuschner C, Temperton VM, von Oheimb G, Fichtner A (2018) Legacy effects of land-use modulate tree growth responses to climate extremes. Oecologia 187:825-837. https://doi.org/10.1007/s00442-0184156-9

Mayor X, Rodà F (1993) Growth response of holm oak (Quercus ilex L) to commercial thinning in the Montseny mountains (NE Spain). Ann Sci For 50:247-256. https://doi.org/10.1051/forest:19930303

Miriti MN (2006) Ontogenetic shift from facilitation to competition in a desert shrub. J Ecol 94:973-979. https://doi.org/10.1111/j.13652745.2006.01138.x 
Montes F, Cañellas I, del Río M et al (2004) The effects of thinning on the structural diversity of coppice forests. Ann For Sci 61:771-779. https://doi.org/10.1051/forest:2004074

Nehrbass-Ahles C, Babst F, Klesse S, Nötzli M, Bouriaud O, Neukom R, Dobbertin M, Frank D (2014) The influence of sampling design on tree-ring-based quantification of forest growth. Glob Chang Biol 20: 2867-2885. https://doi.org/10.1111/gcb.12599

Niinemets Ü (2010) A review of light interception in plant stands from leaf to canopy in different plant functional types and in species with varying shade tolerance. Ecol Res 25:693-714. https://doi.org/10. 1007/s11284-010-0712-4

Palmero-Iniesta M, Espelta JM, Gordillo J, Pino J (2020) Changes in forest landscape patterns resulting from recent afforestation in Europe (1990-2012): defragmentation of pre-existing forest versus new patch proliferation. Ann For Sci

Pemán J, Chirino E, Espelta JM et al (2017) Physiological keys for natural and artificial regeneration of oaks. Oaks Physiological Ecology. Exploring the Functional Diversity of Genus Quercus L. Springer International Publishing, In

Pretzsch H, Biber P, Schütze G et al (2018) Wood density reduced while wood volume growth accelerated in Central European forests since 1870. For Ecol Manag 429:589-616. https://doi.org/10.1016/j. foreco.2018.07.045

Pugh TAM, Lindeskog M, Smith B et al (2019) Role of forest regrowth in global carbon sink dynamics. Proc Natl Acad Sci 116:4382-4387. https://doi.org/10.1073/pnas.1810512116

R Core Team (2018) R: a language and environment for statistical computing. R Foundation for Statistical Computing, Vienna, Austria

Rosengren U, Göransson H, Jönsson U et al (2006) Functional biodiversity aspects on the nutrient sustainability in forests-importance of root distribution. J Sustain For 21:77-100. https://doi.org/10.1300/ J091v21n02 06

Samalens J-C, Rossi J-P (2011) Does landscape composition alter the spatiotemporal distribution of the pine processionary moth in a pine plantation forest? Popul Ecol 53:287-296. https://doi.org/10.1007/ s10144-010-0227-4

Sanchez-Humanes B, Espelta JM (2011) Increased drought reduces acorn production in Quercus ilex coppices: thinning mitigates this effect but only in the short term. Forestry 84:73-82. https://doi.org/10. 1093/forestry/cpq045

Schröter D, Cramer W, Leemans R, Prentice IC, Araújo MB, Arnell NW, Bondeau A, Bugmann H, Carter TR, Gracia CA, de la Vega-Leinert AC, Erhard M, Ewert F, Glendining M, House JI, Kankaanpää S, Klein RJ, Lavorel S, Lindner M, Metzger MJ, Meyer J, Mitchell TD, Reginster I, Rounsevell M, Sabaté S, Sitch S, Smith B, Smith J, Smith P, Sykes MT, Thonicke K, Thuiller W, Tuck G, Zaehle S, Zierl B (2005) Ecosystem service supply and vulnerability to global change in Europe. Science 310:1333-1337. https://doi.org/10.1126/ science. 1115233

Schweingruber FH (1996) Tree rings and environment: dendroecology. Paul Haupt AG Bern, Berne
Schweingruber FH, Eckstein D, Serre-Bachet F, Bräker OU (1990) Identification, presentation and interpretation of event years and pointer years in dendrochronology. Dendrochronologia 8:9-38

Stojanović M, Čater M, Pokorný R (2016) Responses in young Quercus petraea: coppices and standards under favourable and drought conditions. Dendrobiology 76:127-135. https://doi.org/10.12657/ denbio.076.012

Stojanović M, Sánchez-Salguero R, Levanič T et al (2017) Forecasting tree growth in coppiced and high forests in the Czech Republic. The legacy of management drives the coming Quercus petraea climate responses. For Ecol Manag 405:56-68. https://doi.org/10.1016/j. foreco.2017.09.021

Sullivan PF, Csank AZ (2016) Contrasting sampling designs among archived datasets: implications for synthesis efforts. Tree Physiol 36: 1057-1059. https://doi.org/10.1093/treephys/tpw067

Urli M, Lamy J-B, Sin F, Burlett R, Delzon S, Porté AJ (2015) The high vulnerability of Quercus robur to drought at its southern margin paves the way for Quercus ilex. Plant Ecol 216:177-187. https:// doi.org/10.1007/s11258-014-0426-8

Valdés-Correcher E, van Halder I, Barbaro L et al (2019) Insect herbivory and avian insectivory in novel native oak forests: divergent effects of stand size and connectivity. For Ecol Manag 445:146-153. https:// doi.org/10.1016/j.foreco.2019.05.018

Vicente-Serrano SM, Beguería S, López-Moreno JI (2010) A multiscalar drought index sensitive to global warming: the standardized precipitation evapotranspiration index. J Clim 23:1696-1718. https://doi. org/10.1175/2009JCLI2909.1

Vilà-Cabrera A, Espelta JM, Vayreda J, Pino J (2017) "New forests” from the twentieth century are a relevant contribution for $\mathrm{C}$ storage in the Iberian Peninsula. Ecosystems 20:130-143. https://doi.org/10.1007/ s10021-016-0019-6

Williamson GB, Wiemann MC (2010) Measuring wood specific gravity...correctly. Am J Bot 97:519-524. https://doi.org/10.3732/ajb. 0900243

Zang C, Biondi F (2015) treeclim: an R package for the numerical calibration of proxy-climate relationships. Ecography 38:431-436. https://doi.org/10.1111/ecog.01335

Zang C, Pretzsch H, Rothe A (2012) Size-dependent responses to summer drought in scots pine, Norway spruce and common oak. Trees 26:557-569. https://doi.org/10.1007/s00468-011-0617-z

Zhu W-Z, Xiang J-S, Wang S-G, Li M-H (2012) Resprouting ability and mobile carbohydrate reserves in an oak shrubland decline with increasing elevation on the eastern edge of the Qinghai-Tibet Plateau. For Ecol Manag 278:118-126. https://doi.org/10.1016/j.foreco. 2012.04.032

Zuur AF (ed) (2009) Mixed effects models and extensions in ecology with R. Springer, New York, NY

Publisher's note Springer Nature remains neutral with regard to jurisdictional claims in published maps and institutional affiliations. 